\title{
Localized Water Quality Improvement in the Choptank Estuary, a Tributary of Chesapeake Bay
}

\author{
Thomas R. Fisher $^{1}$ (D) Rebecca J. Fox ${ }^{2}$ Anne B. Gustafson ${ }^{1} \cdot$ Erika Koontz $^{1} \cdot$ Michelle Lepori-Bui $^{1,3} \cdot$ James Lewis $^{4}$
}

Received: 14 January 2020 / Revised: 6 August 2020 / Accepted: 16 November 2020 / Published online: 13 January 2021

(C) The Author(s) 2021

\begin{abstract}
Chesapeake Bay has a long history of nutrient pollution resulting in degraded water quality. However, we report improvements in chlorophyll $a$ in surface waters and dissolved oxygen in bottom waters at one of three estuarine stations in the Choptank tributary of Chesapeake Bay. We updated a previous nutrient budget for the estuary constructed for reference year 1998 using rates of atmospheric deposition, inputs of watershed diffuse sources (primarily agriculture), and discharges of point sources (primarily human waste) for reference year 2017. Parallel trends suggest that improvements in water quality at the one station were likely due to $20 \%$ reductions in direct atmospheric deposition on the estuary's surface and 78-95\% reductions in wastewater $\mathrm{N}$ and $\mathrm{P}$ due to installation of tertiary treatment. The agricultural sector, the dominant source of $\mathrm{N}$ and $\mathrm{P}$, appeared to provide little contribution to improved water quality during this period. Although efforts to reduce nutrient losses from agriculture are common throughout the Choptank basin, widespread reductions from agricultural diffuse sources could make large contributions to improved water quality at all stations in the estuary. The response in the Choptank is similar to those observed elsewhere in the USA, Europe, Australia, and New Zealand due to improved wastewater treatment. Similar to our findings, the upper Potomac River of Chesapeake Bay saw improvements driven by reductions in atmospheric deposition. Unfortunately, few studies elsewhere have shown improvements in water quality due to agricultural management. The data presented here indicate that public and industrial investments in reductions of atmospheric emissions and upgrades to wastewater treatment plants have improved estuarine water quality in the Choptank.
\end{abstract}

Keywords Chesapeake Bay $\cdot$ Choptank $\cdot$ Water quality $\cdot$ Atmospheric deposition $\cdot$ Agriculture $\cdot$ Wastewater treatment

\section{Introduction}

The Chesapeake Bay is an estuary which has undergone considerable water quality degradation from anthropogenic point and diffuse sources of $\mathrm{N}$ and $\mathrm{P}$ (Cooper and Brush 1993;

Communicated by Dennis F. Whigham

Thomas R. Fisher

fisher@umces.edu

1 Horn Point Laboratory, Center for Environmental Science, University of Maryland, Cambridge, MD 21613, USA

2 Department of Environmental Science and Studies, Washington College, 300 Washington Ave, Chestertown, MD 21620, USA

3 Department of Ecology, Evolution, and Marine Biology, University of California, Santa Barbara, CA 93106, USA

4 University of Maryland Extension, 9194 Legion Rd, Suite 4, Denton, MD 21629, USA
Kemp et al. 2005). N- and P-rich sources from the atmosphere and land impair use of receiving waters for drinking and recreation, result in algal blooms and hypoxia (Officer et al. 1984; Nixon 1995; Glibert et al. 1995; Harding Jr. and Perry 1997; Follett and Follett 2001; Dagg and Breed 2003; Hagy et al. 2004; Kemp et al. 2005; Harding et al. 2019), and often result in losses of marshlands and submerged aquatic grasses (Orth and Moore 1983; Davis 1985; Deegan et al. 2012). In rural watersheds, most diffuse sources of $\mathrm{N}$ and $\mathrm{P}$ are dominated by agriculture (e.g., David et al. 1997; Lee et al. 2001; van Grieken et al. 2019), whereas in urbanized watersheds, N and $\mathrm{P}$ inputs are primarily from point sources (e.g., Groffman et al. 2003).

Anthropogenic sources of $\mathrm{N}$ and $\mathrm{P}$ can be controlled by a variety of mechanisms. Point sources in most developed countries are typically regulated by environmental agencies, and the costs of nutrient reductions are borne by the industry or municipality via the tax base. In the USA, point sources have discharge permits allocating specific pollution caps (National 
Pollution Discharge Elimination System (NPDES)) and are self-monitored, with data reported to a state or federal environmental agency. Likewise, control of agricultural diffuse sources in developed countries is usually encouraged by government agencies via adoption of agricultural best management practices (BMPs, Ches. Bay Found. 2019). These are typically not monitored, and estimated reductions are based on previous field trials. Agricultural BMPs are conservation practices, such as fertilizer management, drainage control structures, or winter cover crops, that are intended to reduce losses of $\mathrm{N}$ and $\mathrm{P}$ from agricultural fields to surface runoff or groundwater but may not increase cash crop yields. BMPs are largely voluntary and may have benefits for the public but not necessarily for farmers. As a result, BMPs are subsidized by agencies such as the US Dept. of Agriculture and state agencies with incentive payments and "cost-shares" to partially off-set costs to the farmer. Reductions in diffuse nutrient pollution are more challenging and are typically quantified by monitoring of atmospheric deposition or single land uses (e.g., Reckhow et al. 1980; Beaulac and Reckhow 1982; Clesceri et al. 1986; Clark et al. 2000; Schlesinger and Bernhardt 2014), by comparing watersheds with varying amounts of land uses (e.g., Jordan et al. 2003; Fisher et al. 2006a, 2010), or by hydrochemical modeling (e.g., Lee et al. 2001; Alexander et al. 2002).

Recognition of the symptoms of eutrophication in Chesapeake Bay and its causes led to considerable efforts to monitor and reduce the inputs of $\mathrm{N}$ and P (EPA 2010). A total maximum daily load (TMDL) for the Chesapeake was established by the US EPA in 2010 to address degraded water quality, with a goal to achieve by 2025 , a $25 \%, 24 \%$, and $20 \%$ reduction in $\mathrm{N}, \mathrm{P}$, and total suspended solids (TSS), respectively (EPA 2017). Efforts include a major monitoring program in the watershed and estuary (EPA 2018), development of water quality criteria (Harding Jr. et al. 2014), wastewater treatment upgrades (EPA 2016), and implementation of agricultural and urban BMPs (e.g., Hively et al. 2018).

Widespread improvements in water quality have yet to occur in Chesapeake Bay (Hirsch et al. 2010; Liu et al. 2017; Ator et al. 2019; Moyer and Blomquist 2020). However, parts of the Chesapeake have experienced improved water quality, and Gurbisz et al. (2016) and Lefcheck et al. (2018) provided evidence that a partial recovery of submerged grasses in Chesapeake Bay was due to nutrient reductions from watershed sources. In addition, large reductions in sewage $\mathrm{N}$ and $\mathrm{P}$ from the Blue Plains wastewater plant servicing Washington DC and discharging into the Potomac estuary resulted in recovery of submerged grasses in shallow tidal fresh to oligohaline areas of the estuary (Jaworski et al. 2007). Furthermore, Eshleman et al. (2013) provided evidence that diffuse source reductions in the non-tidal Potomac River are related to reductions in atmospheric $\mathrm{N}$ deposition resulting from the 1990 US Clean Air Act Acid Rain Program amendment and other regulatory programs. However, despite these signs of recovery in the tidal fresh Potomac, the tidal saline Potomac estuary shows little sign of change in algal biomass (measured as chlorophyll $a$ ) and bottom water dissolved oxygen (Bricker et al. 2014).

The Choptank is a tributary of Chesapeake Bay on the Delmarva Peninsula (Fig. 1). For the last 20 years, we have worked with farmers, wastewater treatment plant operators, government agencies, and water quality groups to encourage conservation efforts and to discern trends in water quality in the Choptank basin. Here, we evaluate whether the TMDL and other enhanced management of atmospheric deposition, point sources, and agriculture have led to improved water quality in streams and in the Choptank estuary. Our main hypothesis is that management efforts to reduce inputs from the three known nutrient sources in the Choptank watershed (atmospheric deposition, agriculture, waste water) have improved water quality in the Choptank estuary.

\section{Study Site Description}

The Choptank watershed and estuary are components of a coastal plain tributary draining into Chesapeake Bay (Fig. 1). The Choptank watershed lies primarily in the state of Maryland, with a portion in Delaware (Fig. 1). The area has a humid, temperate climate with an average annual precipitation of $1.12 \mathrm{~m}_{\text {year }}{ }^{-1}$. In the estuary, semi-diurnal tides with an amplitude of $\sim 0.5 \mathrm{~m}$ in the lower estuary are amplified by occasional wind tides driven by on-shore and off-shore components of wind. Tides in the upper basin are amplified by the shape of the estuary to as much as $1 \mathrm{~m}$ and penetrate as far upstream as the USGS gauging station at Greensboro MD (Fig. 1).

Eutrophication of the Choptank estuary (Fisher et al. 2006a) is a microcosm of eutrophication in Chesapeake Bay as a whole. For example, agriculture and forests are the dominant land uses in both the Choptank and Chesapeake basins, and population density in the Choptank $\left(59 \mathrm{~km}^{-2}\right.$ in 2000, 52 $\mathrm{km}^{-2}$ in 2010; Fisher et al. 2006a) is similar to other Chesapeake basins $\left(30-70 \mathrm{~km}^{-2}\right.$; Carlozo et al. 2008). As for the Chesapeake (e.g., Kemp et al. 2005), the degradation of the Choptank estuary is well documented (e.g., Staver and Brinsfield 1996; Newell et al. 2004; Benitez and Fisher 2004; Fisher et al. 2006a, b; Sutton et al. 2009). The Choptank watershed and estuary are also focus areas for programs of the US Department of Agriculture (USDA) and US National Oceanographic and Atmospheric Administration (NOAA).

The Choptank basin is well monitored. There is a National Atmospheric Deposition Program (NADP) monitoring station at Wye Mills MD just west of the Choptank basin (nadp.slh.wisc.edu/NADP, station MD013, Fig. 1), and there is a USGS gauging station near Greensboro MD (01491000, 


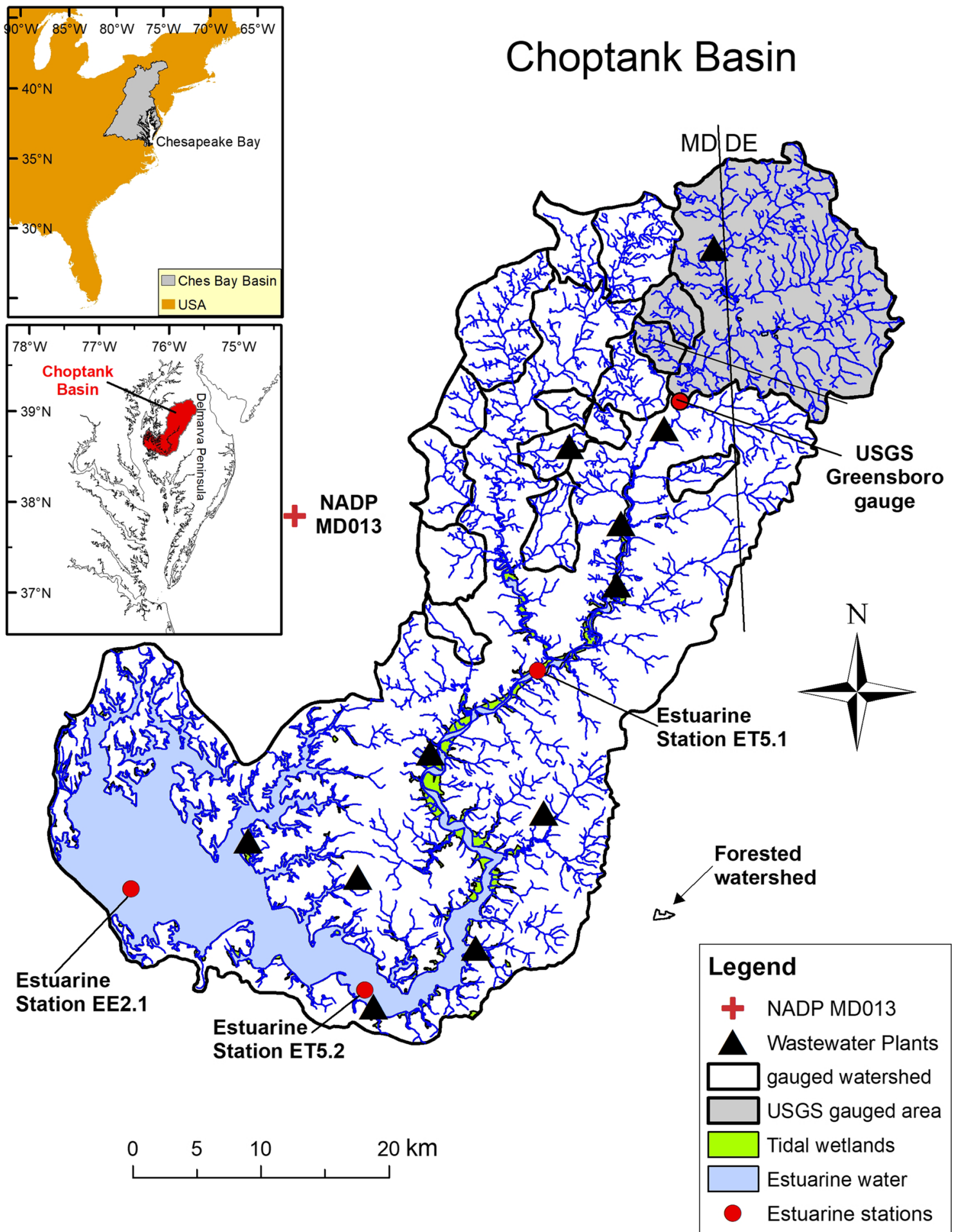

Fig. 1 The Choptank Basin in the Mid-Atlantic region. The USGS gauge at Greensboro MD is shown, along with the gauged watersheds, the nearby forested watershed, the NADP precipitation monitoring station,

$294 \mathrm{~km}^{2}$ in the upper Choptank, hereafter "USGS Greensboro station or watershed"), with a 50-year history of discharge and water quality (Fig. 1; Fisher et al. 1998, 2006a, 2010). Since 2003, we have monitored hydrology and baseflow water chemistry at 15 small watersheds $\left(8-51 \mathrm{~km}^{2}\right)$ dominated by the permitted wastewater treatment plants, and the EPA Bay Program estuarine monitoring stations EE2.1, ET5.2, and ET5.1

agriculture and forest (Fig. 1; Table 1). These monitored watersheds represent $33 \%$ of the area of the Choptank watershed. We have also monitored a small $\left(\sim 2 \mathrm{~km}^{2}\right), 100 \%$ forested watershed (Marshy Hope) in the nearby Nanticoke basin (Fig. 1). The forested watershed is part of the Chesapeake 


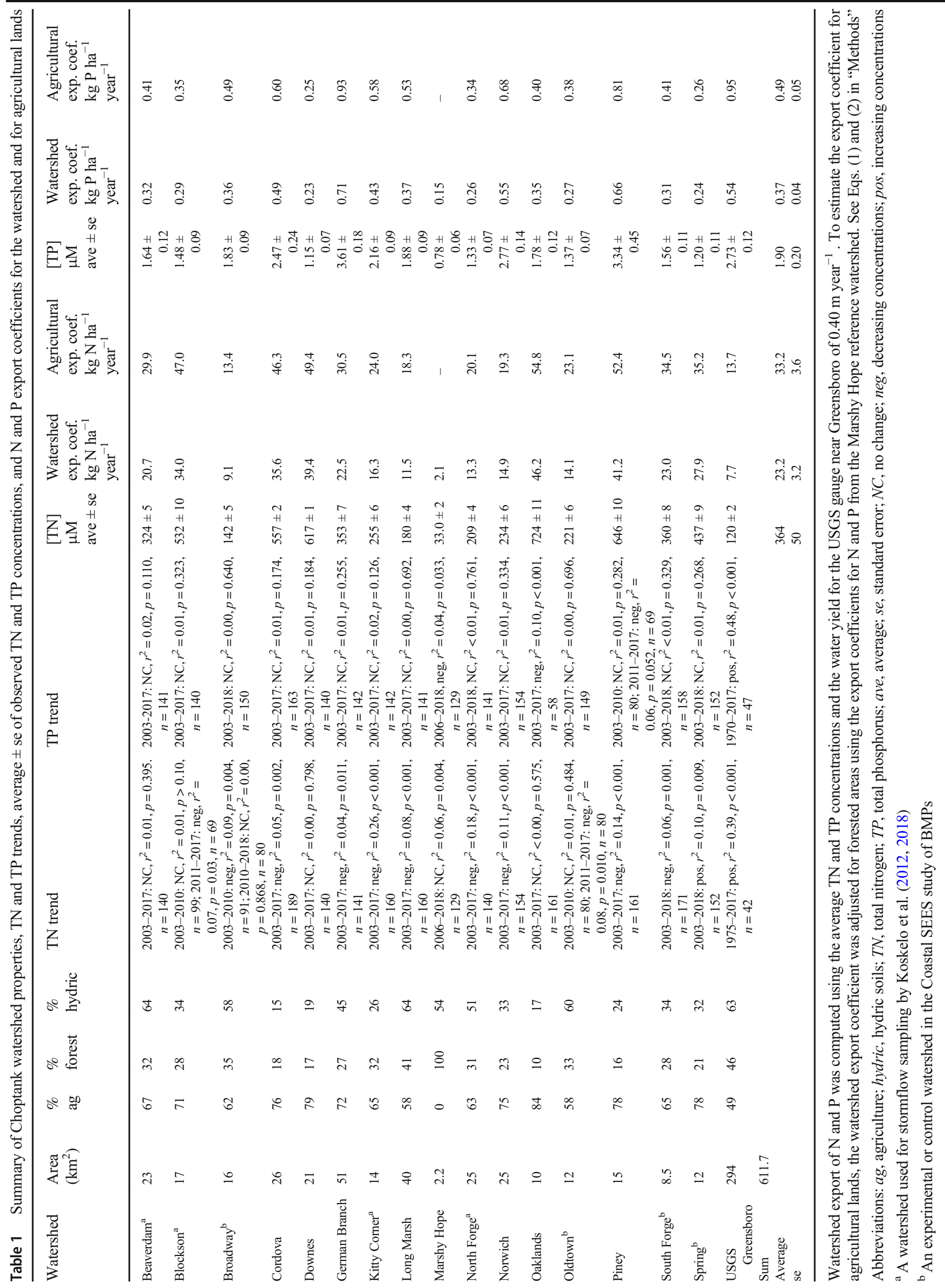


Forest Land managed by MD DNR and is selectively logged at $~ 30$-year intervals. Monitoring details can be found in Fisher et al. (2006a, 2010) and Koskelo et al. (2012, 2018).

There are three estuarine stations monitored since 1984 by the MD Dept. of Natural Resources (Fig. 1). ET5.1 is a tidal fresh station primarily influenced by diffuse agricultural inputs from the watershed: $60 \%$ of the watershed's agricultural lands are upstream of ET5.1, but only $13 \%$ of the watershed's wastewater discharges are upstream (Fig. 1; Table 2). ET5.2 is a mesohaline station near Cambridge MD located $<2 \mathrm{~km}$ downstream from the largest waste water plant in the basin. Station EE2.1 lies near the connection with Chesapeake Bay and is primarily influenced by tidal exchange with bay waters.

Land use in the Choptank basin is representative of the Delmarva landscape. It is dominated by agriculture and forest ( $\sim 60 \%$ and 35\%, respectively; Fisher et al. 2006b, 2010), while the USGS Greensboro watershed is $49 \%$ agricultural and $46 \%$ forested. The primary agricultural products are corn, wheat, and soybeans for poultry feed (Staver and Brinsfield 2001). The watershed contains numerous concentrated animal feeding operations (CAFO, poultry, dairy, beef), which produce manure that is applied as organic fertilizer on crop fields (McCarty et al. 2008). Grain crops and animal production facilities dominate the agricultural land, while forested areas are largely restricted to poorly drained lands where agriculture is unprofitable or housing is impractical (Fisher et al. 2006b). Although the Choptank is primarily agricultural and rural, there are 11 towns serviced by sewage treatment facilities (Table 2). Municipal wastewater treatment plants (WWTPs) in urban areas represent $90-100 \%$ of all point source $\mathrm{N}$ and $\mathrm{P}$ inputs to the Choptank (CAST 2017). Because many urban areas in the Choptank were historically established as easily accessible ports (Cambridge, Easton, Oxford, Secretary), most of the WWTPs discharge into the deeper, stratified portions of the estuary (Fig. 1; Lee et al. 2001).

Basin inputs of $\mathrm{N}$ and $\mathrm{P}$ to the Choptank estuary in the 1990s were estimated by Lee et al. (2001). They reported that atmospheric deposition represented $6 \%$ of $\mathrm{N}$ and $2 \%$ of $\mathrm{P}$ inputs, that agriculture was the dominant source $(90 \% \mathrm{~N}$, $49 \% \mathrm{P}$ ), and that wastewater was responsible for $4 \%$ of $\mathrm{N}$ and $49 \%$ of $\mathrm{P}$ inputs. Here, we compare current inputs of $\mathrm{N}$ and $\mathrm{P}$ from these three sources to those measured in the 1990s.

\section{Methods}

\section{Data Sources}

We have integrated multiple data sources to evaluate longterm changes in inputs of $\mathrm{N}$ and $\mathrm{P}$ from atmospheric deposition, agriculture, and wastewater treatment plants for comparison with changes in estuarine water quality. The data utilized are either publicly available datasets or our own measurements of hydrology, N, and P from small watersheds. We have combined data from these sources to estimate inputs to the Choptank estuary for reference year 2017 for comparison with data reported by Lee et al. (2001) for reference year 1998. The N and P inputs for years 2000-2018 reported here were then used to estimate changes in inputs since 1998 for comparison with trends in estuarine water quality observed in monitoring programs between the years 1998 and 2017.

\section{Atmospheric Deposition}

Inputs of atmospheric inorganic $\mathrm{N}$ were accessed for the local NADP station (Fig. 1). To estimate atmospheric $\mathrm{N}$ deposition to the estuary for reference year 1998, we have not used the atmospheric TN input data reported by Lee et al. (2001). Those values were based on $\sim 1.5$ years of TN samples, and there is considerable interannual variation in $\mathrm{N}$ deposition. To avoid using a single year of $\mathrm{N}$ data for the reference years 1998 and 2017, we used the values predicted for 1998 and 2017 by the regression through all available data (Fig. 2). NADP does not report atmospheric $\mathrm{P}$ or organic $\mathrm{N}$ deposition. Atmospheric TP inputs for reference year 1998 were estimated from the 1.5 years of TP measurements reported by Lee et al. (2001), and to our knowledge, no additional data on atmospheric $\mathrm{P}$ deposition in the Choptank are available.

\section{Monitored Watersheds}

Continuous hydrology data are available from the non-tidal freshwater USGS Greensboro station since 1949 and base flow and storm flow hydrology is available from our 16 monitored watersheds since 2003 (Fig. 1; Fisher et al. 2006a, 2010; Koskelo et al. 2012, 2018; Fox et al. 2014, n.d.). Baseflow here is defined as the discharge in streams from inflowing groundwater after 3 days with no rain, and stormflow is defined as the additional discharge associated with water from precipitation events (direct rainfall, overland flow, shallow throughflow). The separation of base and storm flows in the Choptank basin is described in detail in Koskelo et al. (2012, 2018).

$\mathrm{N}$ and $\mathrm{P}$ concentration data are also available for the USGS Greensboro station and at our monitored watersheds (Fig. 1). USGS data were collected 1-2 times month $^{-1}$ and accessed at the USGS Website (https:// waterdata.usgs.gov/nwis/dv/?site_no $=01491000 \&$ agency $\mathrm{cd}=$ USGS\&amp; referred module $=\mathrm{sw})$. At our forested and agricultural watersheds (Table 2), we have measured nutrient concentrations in baseflow monthly since 2003 to the present. Trends in concentration data were primarily evaluated using linear regression; however, some watersheds exhibited changing trends during 2003-2018, and we used a quadratic or other fit to test 
Table 2 Discharge values for the 11 municipal wastewater treatment plants in the Choptank basin in reference year 2017 after installation of tertiary treatment (Fig. 1)

\begin{tabular}{|c|c|c|c|c|c|c|}
\hline Town & NPDES permit & Treatment & $\begin{array}{l}\text { Year } 2017 \\
\text { ave MGD }\end{array}$ & $\begin{array}{l}\text { Volume } \\
10^{3} \mathrm{~m}^{3} \text { year }^{-1}\end{array}$ & $\begin{array}{l}\text { N output } \\
\text { Mg N year }^{-1}\end{array}$ & $\begin{array}{l}\text { P output } \\
\text { Mg P year }^{-1}\end{array}$ \\
\hline Walkers Trailer Park & MD0057487 & Secondary & 0.01 & 12.7 & 0.00 & 0.038 \\
\hline Greensboro & MD0020290 & ENR 2017 & 0.12 & 165.8 & 2.34 & 0.578 \\
\hline Ridgely & MD0020427 & Secondary & 0.00 & 0.0 & 0.00 & 0.000 \\
\hline North Caroline High & MD0023621 & Secondary & 0.00 & 0.0 & 0.00 & 0.000 \\
\hline Denton & MD0020494 & BNR 2012 & 0.41 & 562.7 & 0.97 & 0.057 \\
\hline Easton & MD0020273 & ENR 2007 & 2.19 & 3023.2 & 3.37 & 0.242 \\
\hline Preston & MD0020621 & ENR 2019 & 0.09 & 128.9 & 0.97 & 0.279 \\
\hline Twin Cities & MD0055352 & $\mathrm{BNR}$ & 0.19 & 263.6 & 2.51 & 0.886 \\
\hline Cambridge & MD0021636 & ENR 2013 & 2.40 & 3313.5 & 9.33 & 0.252 \\
\hline Trappe & MD0020486 & Secondary & 0.08 & 109.4 & 3.05 & 0.011 \\
\hline Oxford & MD0022543 & ENR 2019 & 0.10 & 143.9 & 0.52 & 0.100 \\
\hline Total & & & 5.59 & 7724 & 23.1 & 2.44 \\
\hline
\end{tabular}

NPDES, National Pollution Discharge Elimination System; $M G D, 106$ gallons day ${ }^{-1}=3785 \mathrm{~m}^{3}$ day $^{-1}$; secondary, BOD removal; ENR, enhanced nutrient removal; $B N R$, biological nutrient removal.

for such changes. In these cases, the most recent linear trend over a minimum of 5 years in the data is reported in Table 1. To evaluate the importance of these trends in the water chemistry of monitored areas equitably, the
Fig. 2 Trends in annual precipitation (PPT, mm year ${ }^{-1}$ ), volume-weighted mean DIN $\left(\mathrm{NH}_{4}+\mathrm{NO}_{3}, \mathrm{mg} \mathrm{N} \mathrm{L}^{-1}\right)$, and atmospheric $\mathrm{N}$ deposition $(\mathrm{kg} \mathrm{N}$ $\mathrm{ha}^{-1}$ year $^{-1}$ ) in precipitation at NADP station MD013 just outside of the Choptank basin (Fig. 1). Although precipitation was increasing at $+0.9 \%$ year $^{-1}$, DIN was decreasing at $-1.4 \%$ year $^{-1}$, and atmospheric $\mathrm{N}$ deposition decreased at $-0.9 \%$ year $^{-1}$

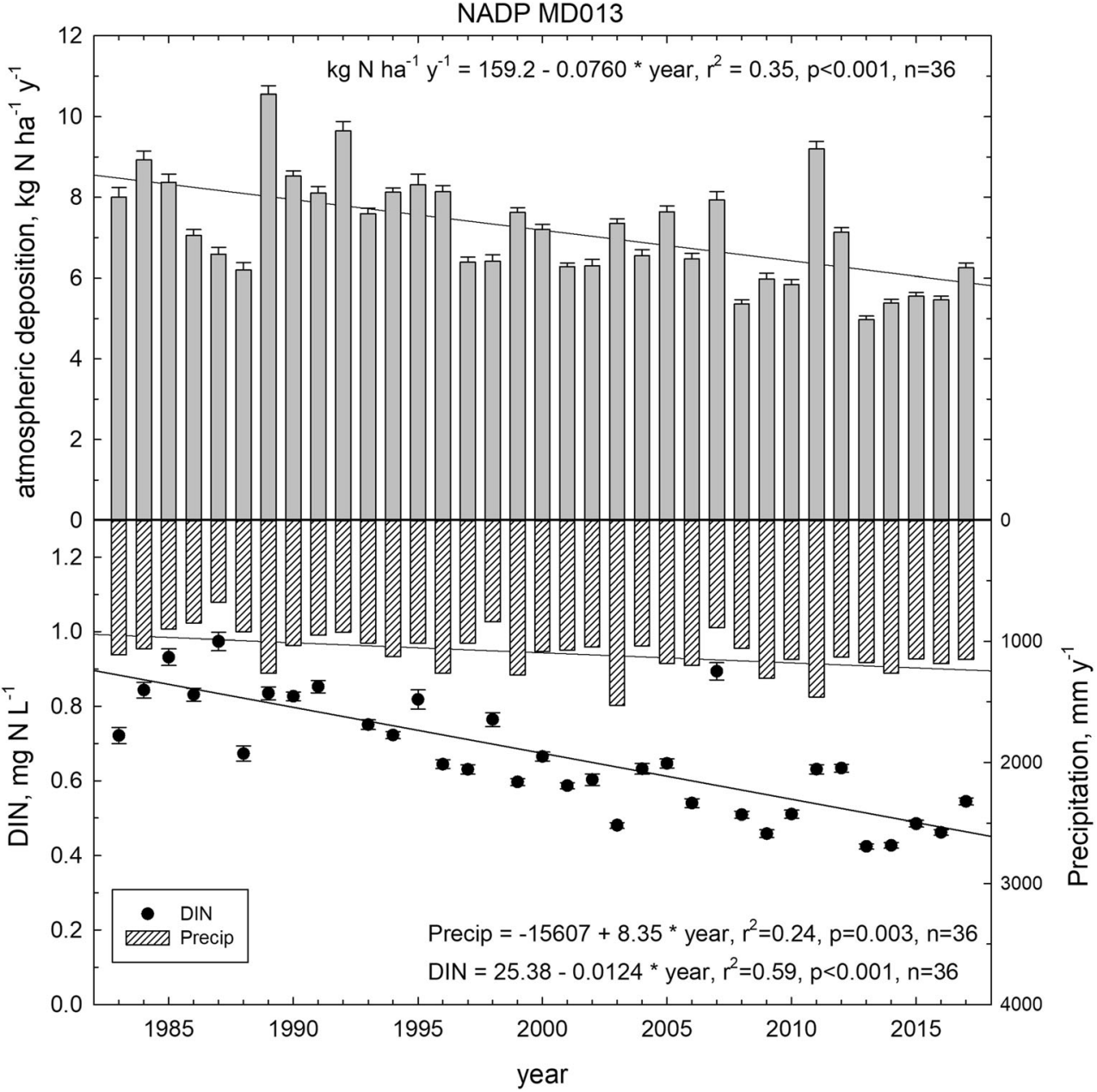


water quality trends were area weighted to account for differences in watershed land areas $\left(2-294 \mathrm{~km}^{2}\right)$.

During 2013 to 2019 , we collected 6-10 volume-weighted mean nutrient concentrations in stormflows at selected watersheds annually. However, we do not yet have sufficient data to capture long-term trends. We have therefore estimated annual $\mathrm{N}$ and $\mathrm{P}$ export from our watersheds using baseflow data corrected by $+14 \%$ for TN and $+64 \%$ for TP according to relationships reported in Koskelo et al. (2018) for the Choptank. The 16-year baseflow data records from these watersheds corrected for storm flows enabled us to evaluate trends in $\mathrm{N}$ and $\mathrm{P}$ concentrations and fluxes from agricultural and forested areas within the Choptank Basin. "Methods" details on these data are provided in Fisher et al. (2006a, b, 2010), Koskelo et al. (2012, 2018), and Fox et al. (2014, n.d.).

\section{Integration of Terrestrial Diffuse Sources}

We combined our direct measurements and those of USGS to compute water yields ( $\mathrm{m} \mathrm{year}^{-1}$ ) and nutrient yield coefficients ( $\mathrm{kg} \mathrm{N}$ or $\mathrm{P} \mathrm{ha}^{-1}$ year $^{-1}$ ) for forested and agricultural land in the 17 monitored watersheds. Monthly baseflow measurements of TN and TP concentrations $\left(\mathrm{mmol} \mathrm{m}^{-3}\right)$ were aggregated by calendar year and combined with long-term mean water yields at the USGS gauging station $\left(0.4 \mathrm{~m}\right.$ year $^{-1}$ $=0.4 \mathrm{~m}^{3} \mathrm{~m}^{-2}$ year $^{-1}$ ) to compute average watershed $\mathrm{N}$ and $\mathrm{P}$ yields $\left(\mathrm{Y}, \mathrm{kg} \mathrm{ha}^{-1}\right.$ year $\left.^{-1}\right)$ after unit adjustments. We used the $100 \%$ forested reference watershed (Marshy Hope, Table 2) to estimate $\mathrm{N}$ and $\mathrm{P}$ export coefficients for forest land ( $Y_{\text {for }}, \mathrm{kg}$ $\mathrm{ha}^{-1}$ year $^{-1}$ ) within each monitored watershed. We used this simplified approach because forest and agriculture in the monitored watersheds represent $91-100 \%$ (average $=96 \%$ ) of the areas of each monitored watershed. The forest contribution to the watershed export coefficient of each watershed was inserted into a simple mass balance:

$Y_{\mathrm{w}} * A_{\mathrm{w}}=Y_{\mathrm{ag}} * A_{\mathrm{ag}}+Y_{\text {for }} * A_{\text {for }}$

where $Y_{\mathrm{w}}, Y_{\mathrm{ag}}$, and $Y_{\text {for }}$ are the watershed, agricultural land, and forested land yield coefficients for $\mathrm{N}$ or $\mathrm{P}\left(\mathrm{kg} \mathrm{ha}^{-1} \mathrm{year}^{-1}\right)$ and $A_{\mathrm{w}}, A_{\mathrm{ag}}$, and $A_{\text {for }}$ are the areas of the watershed, agricultural land, and forested land (ha). Solving for the agricultural contribution $\left(Y_{\mathrm{ag}}\right)$ to $Y_{\mathrm{w}}$, we obtained:

$Y_{\mathrm{ag}}=\frac{\left(Y_{\mathrm{w}} * A_{\mathrm{w}}-Y_{\text {for }} * A_{\text {for }}\right)}{A_{\mathrm{ag}}}$

The forest export coefficients of $2.1 \mathrm{~kg} \mathrm{~N}$ and $0.15 \mathrm{~kg} \mathrm{P}$ $\mathrm{ha}^{-1}$ year $^{-1}$ (Table 1) compare well with those reported in a review of the biogeochemistry of relatively undisturbed forests in the USA $\left(0.9 \mathrm{~kg} \mathrm{~N}\right.$ and $0.1 \mathrm{~kg} \mathrm{P} \mathrm{ha}^{-1}$ year $\left.^{-1}\right)$ by Clark et al. (2000); however, our forest export coefficients are slightly elevated, probably due to periodic harvest activity similar to forested areas within our agricultural watersheds.
The measured $Y_{\text {for }}$ and average $Y_{\mathrm{ag}}$ coefficients of monitored areas (33\% of land; Table 1) were used to extrapolate over unmonitored areas within the Choptank basin (67\% of land). Using the monitored watersheds as samples of the unmonitored areas, terrestrial inputs from unmonitored land areas were obtained from land use information in unmonitored areas (Fisher et al. 2006b) combined with $Y_{\text {for }}$ and $Y_{\text {ag }}$ in monitored areas. Inputs of directly measured watersheds and estimated inputs from unmonitored areas were then combined as total terrestrial inputs.

\section{Wastewater treatment plants}

Discharge and chemistry data were accessed for the 11 wastewater treatment plants with NPDES permits within the Choptank Basin (see Fig. 1). We used the database of the Chesapeake Area Scenario Tool (CAST 2017) to obtain measurements of annual export of $\mathrm{N}$ and $\mathrm{P}$ reported by each facility. Using the urban collection areas of each wastewater plant from Lee et al. (2001) and the CAST wastewater data, we calculated $\mathrm{N}$ and $\mathrm{P}$ yield coefficients for wastewater inputs as we have for forested and agricultural lands in our watersheds (Table 3).

\section{Estuarine water quality stations}

There is a 34-year history of estuarine water quality testing by MD Dept. Natural Resources and the EPA Bay Program. Data on Secchi depth and N, P, and chlorophyll $a$ concentrations at the three monitoring stations in the Choptank (Fig. 1) were obtained from the Chesapeake Information Management System (CIMS, https://www.chesapeakebay.net/what/ downloads /cbp_water_quality_database_1984_present) to examine long-term trends in estuarine water quality.

\section{GIS, Graphics, and Statistics}

ET5.1 and ET5.2 station watershed boundaries were based on the Choptank Basin boundary and 12 digit watersheds (https:// data.imap.maryland.gov/datasets/maryland-watersheds-12digit-watersheds). Portions of the watershed boundaries were digitized along the midpoints between stream reaches using ArcMap v12.5. Curve fitting and statistical tests for water quality trends were done within SigmaPlot v12.5, and parametric or non-parametric tests were used as appropriate. The use of a linear vs. quadratic or other models for concentration trends was determined based on the Akaike Information Criterion (AIC, Akaike 1973):

$\mathrm{AIC}=n * \ln ($ SSerror $/ n)+2 * K$

where $n$ is sample size, SSerror is sum of squares error, and $K$ is number of model parameters +1 . The model with $p<0.05$ 
Table 3 Summary of inputs to Choptank Estuary

\begin{tabular}{|c|c|c|c|c|c|c|c|c|c|c|c|c|c|c|c|c|}
\hline \multirow[t]{3}{*}{ Input } & \multirow{3}{*}{$\begin{array}{l}\text { Relevant } \\
\text { area }\end{array}$} & \multirow[t]{3}{*}{ ha } & \multicolumn{7}{|c|}{ Nitrogen } & \multicolumn{7}{|c|}{ Phosphorus } \\
\hline & & & \multicolumn{3}{|c|}{$\begin{array}{l}\text { 1983-2000 (Lee et al. } \\
\text { 2001) }\end{array}$} & \multicolumn{4}{|c|}{ 2001-2018 update } & \multicolumn{3}{|c|}{$\begin{array}{l}\text { 1983-2000 (Lee et al. } \\
2001)\end{array}$} & \multicolumn{4}{|c|}{ 2001-2018 update } \\
\hline & & & $\begin{array}{l}\mathrm{kg} \mathrm{N} \\
\text { ha }^{-1} \\
\text { year }^{-1}\end{array}$ & $\begin{array}{l}\mathrm{Mg} \\
\mathrm{Ny}^{-1} \\
\text { input }\end{array}$ & $\begin{array}{l}\% \text { of } \\
\text { total } \\
\mathrm{N} \\
\text { input }\end{array}$ & $\begin{array}{l}\mathrm{kg} \mathrm{N} \\
\text { ha }^{-1} \\
\text { year }^{-1}\end{array}$ & $\begin{array}{l}\mathrm{Mg} \\
\mathrm{N} \mathrm{y}^{-1} \\
\text { input }\end{array}$ & $\begin{array}{l}\% \text { of } \\
\text { total } \\
\mathrm{N} \\
\text { input }\end{array}$ & $\begin{array}{l}\% \mathrm{~N} \\
\text { change }\end{array}$ & $\begin{array}{l}\mathrm{kg} \mathrm{P} \\
\text { ha }^{-1} \\
\text { year }^{-1}\end{array}$ & $\begin{array}{l}\text { Mg P } \\
\text { year }^{-1} \\
\text { input }\end{array}$ & $\begin{array}{l}\% \text { of } \\
\text { total P } \\
\text { input }\end{array}$ & $\begin{array}{l}\text { kg P } \\
\text { ha }^{-1} \\
\text { year }^{-1}\end{array}$ & $\begin{array}{l}\text { Mg P } \\
\text { year }^{-1} \\
\text { input }\end{array}$ & $\begin{array}{l}\% \text { of } \\
\text { total P } \\
\text { input }\end{array}$ & $\begin{array}{l}\% \mathrm{P} \\
\text { change }\end{array}$ \\
\hline $\begin{array}{r}\text { Atmospheric } \\
\text { deposition }\end{array}$ & $\begin{array}{l}\text { Estuary } \\
\quad \text { surface }\end{array}$ & 28,029 & 5.5 & 155 & 6.2 & 6.0 & 168 & 4.4 & 9 & 0.04 & 1.1 & 1.9 & NA & NA & NA & NA \\
\hline Agriculture & $\begin{array}{c}61 \% \text { of } \\
\text { land }\end{array}$ & 107,100 & 20.3 & 2178 & 87.7 & 33.2 & 3558 & 91.9 & +63 & 0.21 & 22.6 & 39.3 & 0.49 & 53.0 & 76.9 & +134 \\
\hline Forests & $\begin{array}{r}33 \% \text { of } \\
\text { land }\end{array}$ & 57,939 & 0.9 & 52.1 & 2.1 & 2.1 & 122 & 3.2 & +134 & 0.10 & 5.8 & 10.1 & 0.15 & 8.9 & 12.9 & +54 \\
\hline $\begin{array}{l}\text { Wastewater } \\
\text { plants (10) }\end{array}$ & $\begin{array}{c}2.3 \% \text { of } \\
\text { land }\end{array}$ & 4055 & 24.2 & 98.2 & 4.0 & 5.7 & 23.1 & 0.6 & -76 & 6.9 & 28.1 & 48.8 & 1.73 & 7.0 & 10.2 & -91 \\
\hline Totals & $\begin{array}{l}\text { Land + } \\
\text { estuary }\end{array}$ & 203,602 & & 2483 & 100 & & 3872 & 100 & +56 & & 58 & 100 & & 69 & 100 & +20 \\
\hline
\end{tabular}

Atmospheric N deposition was estimated from the regression in Fig. 2 for years 1998 and 2017, and the \% N and P change in 2017 was computed from the values in 1998 and 2017. P deposition in 1998 was based on unpublished P measurements at MD013 during 1995-2000; no P deposition data are available for 2001-2017. Forest N and P inputs were based on export coefficients measured at the Marshy Hope forested reference watershed (see Table 1). Agricultural inputs were obtained by subtracting the forest component from terrestrial diffuse sources in in each watershed (Table 1), and the average yield coefficient for agricultural land was applied to all agricultural areas in the Choptank basin. Wastewater $\mathrm{N}$ and $\mathrm{P}$ inputs were obtained from CAST, and the $\mathrm{N}$ and P reductions were computed from the average of 1983-2000 prior to tertiary treatment and the value in 2017 following teriary treatment (Fig. 5)

and the lowest AIC score was chosen. If models had similar AIC values $( \pm 7)$, we chose the more complex model (Burnham and Anderson 2002).

\section{Results}

\section{Nutrient Inputs}

\section{Atmospheric Deposition}

Regional atmospheric deposition of dissolved inorganic $\mathrm{N}$ (DIN $=\mathrm{NO}_{3}{ }^{-}+\mathrm{NO}_{2}{ }^{-}+\mathrm{NH}_{4}{ }^{+}$) on the estuarine surface was the second largest $\mathrm{N}$ source in the Choptank (Table 3). DIN data from the nearby NADP station for 1983-2017 (Fig. 2) showed a long-term, volume-weighted mean \pm se of $48 \pm$ $2 \mu \mathrm{M}\left(0.67 \pm 0.03 \mathrm{mg} \mathrm{N} \mathrm{L}^{-1}\right)$, with a linear decrease in annual average DIN concentrations $\left(r^{2}=0.59, p<0.001, n=35\right)$ in precipitation of $-0.89 \mu \mathrm{mol} \mathrm{L}^{-1}$ year $^{-1}\left(-0.012 \mathrm{mg} \mathrm{N} \mathrm{L}^{-1}\right.$ year $^{-1}$, equivalent to $-1.4 \%$ year $^{-1}$; Fig. 2 , lower panel). Over the same time period, annual precipitation depth averaged $1093 \pm 29 \mathrm{~mm}$ year $^{-1}$ and increased by $\sim 9 \mathrm{~mm}$ year $^{-1}$ ( $0.9 \%$ year $\left.^{-1}, r^{2}=0.24, p=0.003, n=35\right)$, partially cancelling the effects of decreasing DIN concentrations. The DIN flux from wet precipitation averaged $7.2 \pm 0.2 \mathrm{~kg} \mathrm{~N} \mathrm{ha}^{-1}$ year $^{-1}$ over the period of record, and despite the opposing trends in concentrations and precipitation, the DIN flux decreased by -
$0.075 \mathrm{~kg} \mathrm{~N} \mathrm{ha}^{-1}$ year $^{-2}\left(-0.9 \%\right.$ year $^{-1}, r^{2}=0.35, p<0.001, n$ $=35$, Fig. 2 , upper panel). Revised inputs to the estuary from atmospheric deposition were predicted from the regression in Fig. 2 to estimate deposition in both reference years. This resulted in $\mathrm{N}$ deposition of 7.4 and $6.0 \mathrm{~kg} \mathrm{~N} \mathrm{ha}^{-1}$ year $^{-1}$ for 1998 and 2017, respectively, a 20\% decrease consistent with the entire NADP dataset (Fig. 2).

\section{Terrestrial Diffuse Sources}

Agriculture was the largest $\mathrm{N}$ and $\mathrm{P}$ source in the Choptank (Table 3). At the USGS Greensboro station (Fig. 1), annually averaged $\mathrm{N}$ and $\mathrm{P}$ concentrations steadily increased during 1964-2017 (TN: $r^{2}=0.39, p<0.001, n=37$; TP: $r^{2}=0.61$, $p<0.001, n=48$; Fig. 3). The 15 smaller agricultural watersheds (Table 1; Fig. 1) exhibited higher concentrations, but less consistent patterns in terms of $\mathrm{N}$ and $\mathrm{P}$ trends from 2003 2018. For baseflow TP, no agricultural watersheds exhibited increases in concentrations, 11 had no changes, and two decreased. For baseflow TN, one agricultural watershed showed increases in TN, 4 showed no changes, and 10 showed decreases (Table 1). Figure 4 shows the extremes of the baseflow concentration trends observed at the outlets of the small agricultural watersheds. At South Forge watershed there was a $2.8 \%$ year $^{-1}$ decrease in TN after 2008 (Fig. 4, left). In contrast, TN at Spring watershed steadily increased by $1.2 \%$ year ${ }^{-1}$ during 2003-2018 (Fig. 4, right). Despite the decreases 
Fig. 3 Interannual trends in $\mathrm{N}$ and $P$ concentrations at the USGS near Greensboro in the upper Choptank basin (Fig. 1)

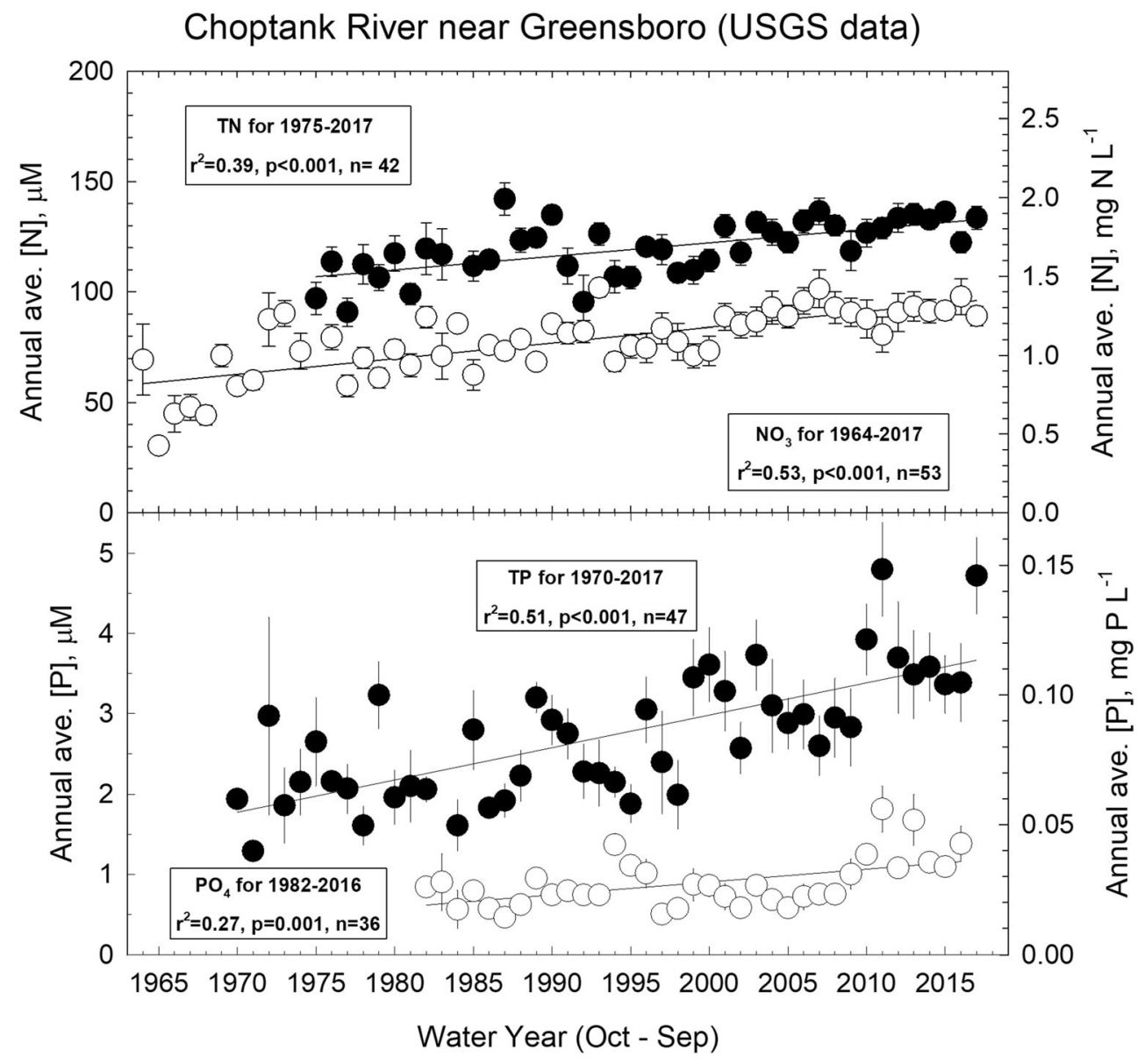

in TN draining from 10 of the 15 agricultural watersheds, the concentrations remained high (Figs. 3 and 4; Table 1).

Area-weighted trends of all monitored watersheds were used to evaluate changes in water quality in the entire monitored area of the Choptank. This revealed that 53 and $55 \%$ of the monitored area showed increasing concentrations of $\mathrm{N}$ and $\mathrm{P}$, respectively; 9 and $41 \%$ showed no changes in $\mathrm{N}$ and $\mathrm{P}$, and 38 and $4 \%$ showed decreases in $\mathrm{N}$ and $\mathrm{P}$

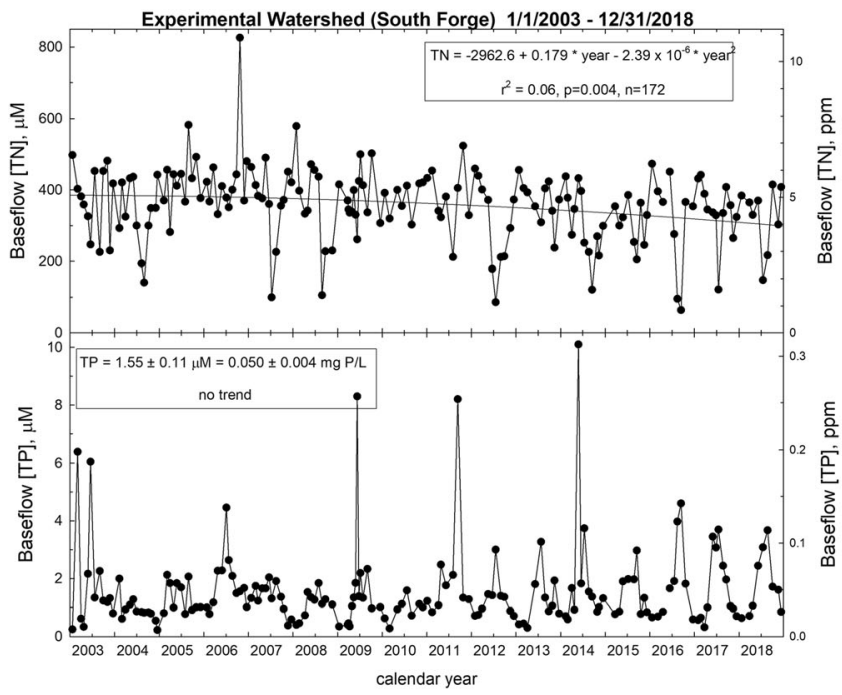

Fig. 4 Trends in monthly $\mathrm{N}$ and $\mathrm{P}$ concentrations at two of the agriculturally dominated watersheds in the upper Choptank basin (Fig. 1). Both South Forge and Spring were experimental watersheds with

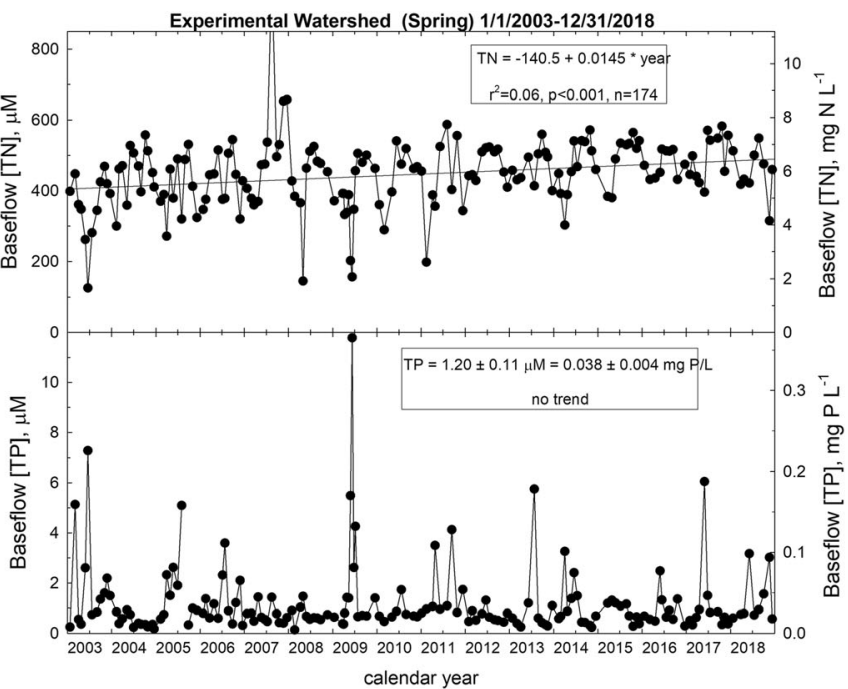

enhanced BMPs, and these examples illustrate the range of agricultural watershed responses to BMP additions 
concentrations. Overall, we observed increasing or stable concentrations of TN and TP in 62 and $96 \%$ of the monitored agricultural watersheds, respectively, providing little evidence of widespread improvements in water quality.

Yield coefficients for agricultural land in 2017 were estimated for each monitored watershed (Table 1; Eq. 2). $Y_{\text {ag }}$ estimated for the individual watersheds varied over 13-55 $\mathrm{kg} \mathrm{N}$ and $0.25-0.96 \mathrm{~kg} \mathrm{P} \mathrm{ha}^{-1}$ year $^{-1}$, averaging $33 \pm 4 \mathrm{~kg}$ $\mathrm{N}$ and $0.49 \pm 0.05 \mathrm{~kg} \mathrm{Pha}^{-1}$ year $^{-1}$. These values for reference year 2017 (Table 1) represented an increase compared to the reference year 1998 compiled by Lee et al. (2001), who reported average export coefficients for agriculture of $20 \mathrm{~kg} \mathrm{~N}$ and $0.21 \mathrm{~kg} \mathrm{P} \mathrm{ha}^{-1}$ year $^{-1}$.

Total watershed inputs of terrestrial diffuse sources to the Choptank estuary from agriculture and forests are shown in Table 3. There are no data available on urban diffuse sources, but this land use is only $6 \%$ of the land area of the Choptank basin. Terrestrial diffuse sources of $\mathrm{N}$ and $\mathrm{P}$ from forested and agricultural lands increased between the two reference years partially due to inclusion of storm flow inputs, which were not available in 1998, and partially due to observed changes in water quality for reference year 2017. Terrestrial $\mathrm{N}$ inputs (forest + agriculture) to the estuary increased by $65 \%$ from 2230 to $3680 \mathrm{Mg} \mathrm{N}$ year $^{-1}$, primarily due to agricultural contributions (86-93\% of the total). Terrestrial $\mathrm{P}$ inputs increased by $>300 \%$ from 16.8 to $61.9 \mathrm{Mg} \mathrm{P}$ year ${ }^{-1}$, also primarily due to agriculture (39-77\%) and our inclusion of stormflow $\mathrm{P}$ in the estimates.

\section{Terrestrial Point Sources}

There have been large changes in the treatment of human sewage in the Choptank basin. In the 1980s, all WWTPs had at most secondary treatment, with large and variable discharges augmented by combined storm and wastewater lines (Fig. 5, top panel). Discharge volumes increased during the 1980s and 1990s and then slowly declined after 2000 due to installation of separate storm drains in the 1990s. Export of N and P from the wastewater plants was also large and variable during 1984-2001, but most WWTPs in the Choptank were upgraded to tertiary treatment after 2000 using wastewater taxes imposed by the state of MD (Chesapeake Bay Restoration Act or "flush tax"). The advanced tertiary treatment installed during 2000-2010 and declining discharge volumes resulted in exponentially decreasing discharges of $\mathrm{N}$ (78\%) and P (91\%) for all plants by 2017, including the Cambridge WWTP (Fig. 5, middle and lower panels).

Inputs are a function of both intensity (yield coefficient, $\mathrm{kg}$ $\mathrm{ha}^{-1}$ year $^{-1}$ ) and area (ha). Normalizing point sources to their collection areas enables comparisons with the yield coefficients of other inputs. During 1988-2000, the data of Lee et al. (2001) resulted in wastewater $\mathrm{N}$ yield coefficients (24 $\mathrm{kg} \mathrm{N} \mathrm{ha}^{-1}$ year $^{-1}$ ) somewhat higher than the average for agricultural lands ( $20 \mathrm{~kg} \mathrm{~N} \mathrm{ha}^{-1}$ year $\left.^{-1}\right)$; however, the wastewater P coefficients during 1988-2000 (6.9 kg P ha ${ }^{-1}$ year $^{-1}$ ) were more than an order of magnitude higher than agricultural diffuse sources $\left(0.21 \mathrm{~kg} \mathrm{P} \mathrm{ha}^{-1}\right.$ year $\left.^{-1}\right)$. In contrast, the data reported here for 2001-2018 after advanced tertiary treatment show greatly reduced coefficients of $5.7 \mathrm{~kg} \mathrm{~N} \mathrm{ha}^{-1}$ year $^{-1}$ (smaller than atmospheric $\mathrm{N}$ deposition) and $1.7 \mathrm{~kg} \mathrm{P} \mathrm{ha}^{-1}$ year $^{-1}$, lower than in the 1990 s, but still the highest $\mathrm{P}$ yield coefficient.

\section{Summary of Inputs}

Total estimated $\mathrm{N}$ and $\mathrm{P}$ inputs to the Choptank estuary increased between the two time periods (Table 3). During 19882000, atmospheric and terrestrial $\mathrm{N}$ inputs to the estuary were $2483 \mathrm{Mg} \mathrm{N}$ year $^{-1}, 88 \%$ of which were contributed by agriculture. The $\mathrm{N}$ inputs increased to $3872 \mathrm{Mg} \mathrm{N}$ year $^{-1}$ in $2001-$ 2017 , a $53 \%$ increase, which was primarily due to increasing $\mathrm{N}$ from terrestrial diffuse sources (Table 1). Agriculture was responsible for $92 \%$ of the inputs calculated for reference year 2017 , and the remaining inputs were $<5 \%$ each. Unfortunately, the decreases in atmospheric $\mathrm{N}$ deposition (19\% from the 1998 estimates) and wastewater $\mathrm{N}$ discharges ($76 \%$ ) were overwhelmed by the increases in agricultural $\mathrm{N}$.

$\mathrm{P}$ inputs to the Choptank estuary also increased by $20 \%$ from the earlier to later time period estimates (Table 3 ). In the earlier time period, $\mathrm{P}$ inputs were $58 \mathrm{Mg} \mathrm{P}$ year ${ }^{-1}$, primarily from wastewater plants $\left(28 \mathrm{Mg} \mathrm{year}^{-1}\right)$ and agriculture (23 Mg year ${ }^{-1}$ ). However, during 2001-2018, there were 91\% decreases in wastewater P inputs, making current wastewater $\mathrm{P}$ the smallest input for which data are available. There are currently no measurements that we are aware of for atmospheric P deposition in the Choptank, but it is likely that atmospheric $\mathrm{P}$ input to the estuary is much smaller than current wastewater inputs, given the values measured by Lee et al. (2001; Table 3). Agricultural inputs increased from 1988 to 2000 (23 Mg P year ${ }^{-1}$ ) to 2001-2018 (53 Mg P year ${ }^{-1}$ ). Overall, estimated $\mathrm{P}$ inputs to the estuary have increased from 58 to $69 \mathrm{Mg} \mathrm{P}$ year ${ }^{-1}$ for the two time periods.

\section{The Choptank Estuary}

Estuarine station ET5.1 is the most upstream sampling location in the estuary (Fig. 1). ET5.1 had the highest average chlorophyll $a$ concentrations, most shallow Secchi depth, and highest average $\mathrm{N}$ and $\mathrm{P}$ concentrations of any river sampling location, including the USGS Greensboro station (Table 4; Fig. 6). Annual average chlorophyll $a$ concentrations were high during 1984-1998 (20-30 $\left.\mathrm{g} \mathrm{L} \mathrm{L}^{-1}\right)$, and then steadily declined during $1998-2005$ to $5-12 \mu \mathrm{g} \mathrm{L}^{-1}$, largely remaining at these concentrations through 2018 (Fig. 6). Summer bottom dissolved $\mathrm{O}_{2}$ was close to atmospheric equilibrium $\left(\sim 7 \mathrm{mg} \mathrm{O}_{2} \mathrm{~L}^{-1}\right)$ in 1984 , and then steadily declined during 
Fig. 5 Trends in discharges from all Choptank WWTPs and the Cambridge WWTP. Data source: CAST, Chesapeake Assessment Scenario Tool; BNR, biological nutrient reduction; ENR, enhanced nutrient reduction

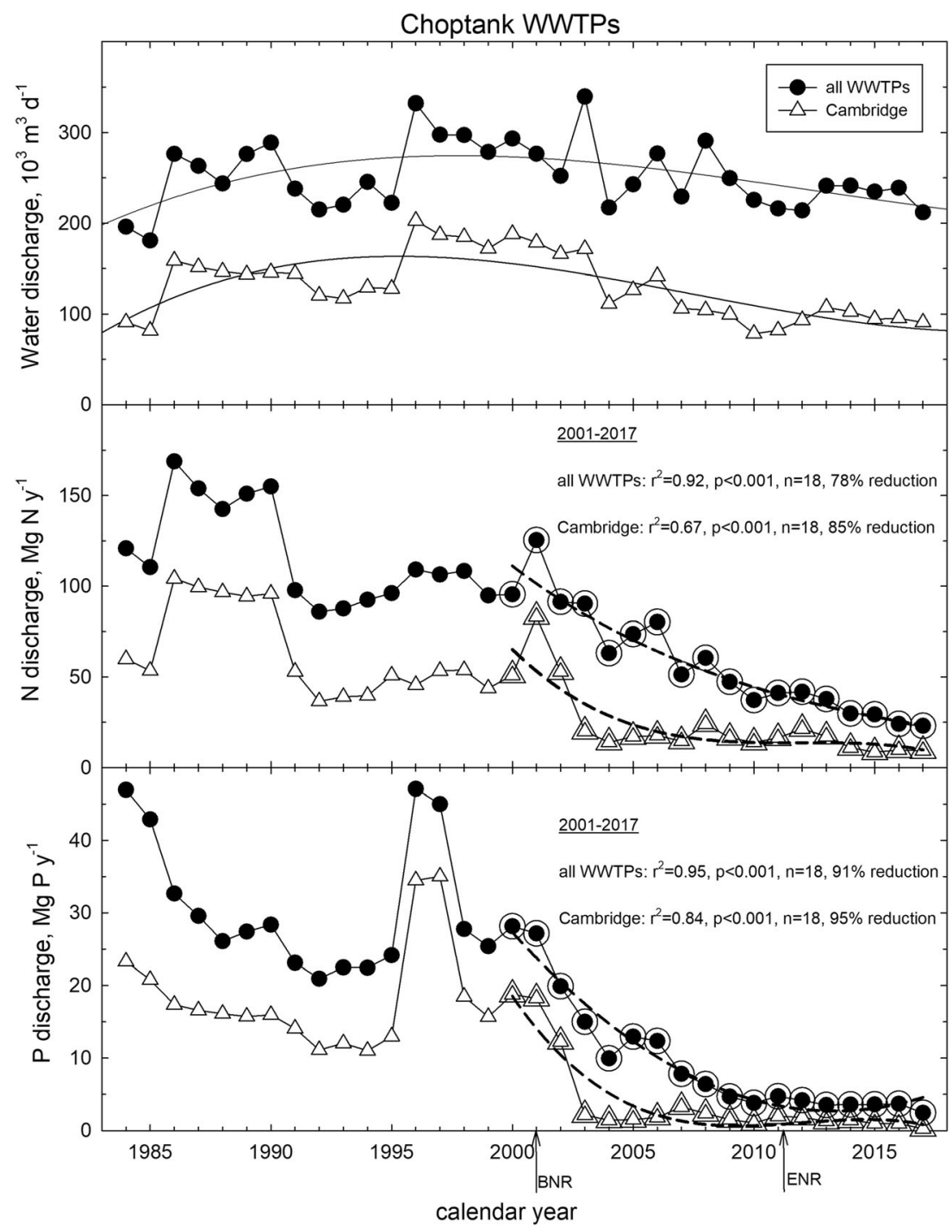

most of the monitoring period to under-saturated values of 4 $6 \mathrm{mg} \mathrm{O} \mathrm{L}^{-1}$. Secchi depths were shallow $(\sim 0.3 \mathrm{~m})$ and remained unchanged during the entire period.

Mesohaline estuarine station ET5.2 lies further downstream in the estuary near Cambridge MD (Fig. 1). During 1984-2005, this station exhibited degrading water quality, with increases in annual average chlorophyll $a$ in surface waters and decreases in summer bottom dissolved $\mathrm{O}_{2}$ and Secchi depths (Fisher et al. 2006a, 2010; Fig. 7). However, after 2005 chlorophyll $a$ concentrations stabilized and then slightly decreased. Furthermore, $\mathrm{O}_{2}$ concentrations in bottom waters started to increase, and Secchi depth increased. These recent changes in water quality occurred as our estimates of current $\mathrm{N}$ and $\mathrm{P}$ inputs to the estuary were increasing (Table 3) but corresponded closely in time with reductions in wastewater $\mathrm{N}$ and $\mathrm{P}$ inputs (Fig. 5), much of which occurred at the Cambridge wastewater treatment plant $<2 \mathrm{~km}$ upstream from estuarine station ET5.2.
Station EE2.1 is the outermost mesohaline estuarine station in the Choptank near the main stem of Chesapeake Bay (Fig. 1). At EE2.1, chlorophyll $a$ steadily increased from 5-10 to 10-20 $\mathrm{g} \mathrm{L} \mathrm{L}^{-1}$ during 1984-2018 (Fig. 8), gradually converging with chlorophyll $a$ concentrations at station ET5.2 (Fig. 7). Summer bottom dissolved $\mathrm{O}_{2}$ was under-saturated at EE2.1 (4-7 mg $\mathrm{O}_{2} \mathrm{~L}^{-1}$ ), with no trend during 1984-2018, and was similar to the improving values at ET5.2 after 2015. Secchi depths at EE2.1 decreased from $1.5-2.0 \mathrm{~m}$ in the $1980 \mathrm{~s}$ to 1.0 $1.5 \mathrm{~m}$ in $2015-2018$, in parallel with increasing concentrations of chlorophyll $a$.

\section{Discussion}

\section{Spatial and Temporal Patterns}

We have shown that there were changes in nutrient inputs to the Choptank estuary between reference years 1998 and 2017. 
Table 4 Summary of mean station properties in the Choptank River and estuary for 1984-2018

\begin{tabular}{|c|c|c|c|c|c|c|c|c|c|c|c|c|}
\hline Station & Type & $\begin{array}{l}\text { Estuarine } \\
\text { Structure }\end{array}$ & $\begin{array}{l}\% \text { ag area } \\
\text { Upstream }\end{array}$ & $\begin{array}{l}\% \\
\text { wastewater } \\
\text { Output } \\
\text { upstream }\end{array}$ & $\begin{array}{l}\text { Depth } \\
\text { (m) }\end{array}$ & $\begin{array}{l}\text { Mean } \\
\text { TN } \\
(\mu \mathrm{M})\end{array}$ & $\begin{array}{l}\text { Mean } \\
\mathrm{NO}_{3} \\
(\mu \mathrm{M})\end{array}$ & $\begin{array}{l}\text { Mean } \\
\text { TP } \\
(\mu \mathrm{M})\end{array}$ & $\begin{array}{l}\text { Mean } \\
\mathrm{PO}_{4} \\
(\mu \mathrm{M})\end{array}$ & $\begin{array}{l}\text { Mean } \\
\text { chla } \\
\mu g \text { L }^{-1}\end{array}$ & $\begin{array}{l}\text { Mean bot } \\
\text { DO (mg } \\
\left.\mathrm{L}^{-1}\right)\end{array}$ & $\begin{array}{l}\text { Mean } \\
\text { Secchi } \\
(\mathrm{m})\end{array}$ \\
\hline 01491 & $\begin{array}{l}\text { Non-tidal } \\
\text { fresh }\end{array}$ & $\begin{array}{l}\text { Terr. diffuse } \\
\text { inputs }\end{array}$ & 13 & 8 & 0.8 & 120 & 77.8 & 2.73 & 0.89 & NA & NA & NA \\
\hline ET5.1 & Tidal fresh & $\begin{array}{l}\text { Turbidity } \\
\text { maximum }\end{array}$ & 60 & 13 & 10.0 & 164 & 96.4 & 4.06 & 0.89 & 16.5 & 5.72 & 0.34 \\
\hline ET5.2 & $\begin{array}{l}\text { Tidal } \\
\text { mesohaline }\end{array}$ & chla maximum & 85 & 98 & 13.3 & 71.4 & 20.7 & 1.90 & 0.43 & 13.1 & 4.61 & 1.00 \\
\hline EE2.1 & $\begin{array}{l}\text { Tidal } \\
\text { mesohaline }\end{array}$ & $\begin{array}{l}\text { Ches Bay } \\
\text { connection }\end{array}$ & 100 & 100 & 12.7 & 52.1 & 12.1 & 1.16 & 0.19 & 10.6 & 5.54 & 1.46 \\
\hline
\end{tabular}

$\%$ agricultural area upstream and $\%$ wastewater output upstream are the fraction of the total area or output of the basin within the drainage of each station Abbreviations: ag, agriculture; bot DO, summer bottom dissolved $\mathrm{O}_{2}$; 01491, USGS Greensboro station; terr., terrestrial; NA, not available; chla, chlorophyll $a$; Ches, Chesapeake

Atmospheric $\mathrm{N}$ deposition to the estuarine surface was the second largest $\mathrm{N}$ input to the estuary (Table 3 ) but decreased at $-0.075 \mathrm{~kg} \mathrm{~N} \mathrm{ha}^{-1}$ year $^{-1}$, or approximately $-0.9 \% \mathrm{~N}$ year $^{-1}$, for a total reduction of $20 \%$ between 1998 and 2017 (Fig. 2). Decreases in atmospheric $\mathrm{N}$ deposition via precipitation are commonly observed in the Eastern USA (e.g.,
Fig. 6 Trends in annually averaged surface chlorophyll $a$, July-Sept bottom-dissolved oxygen and annual average Secchi depth at the tidal fresh stations ET5.1 near the turbidity maximum in the Choptank estuary. Data source: MD DNR

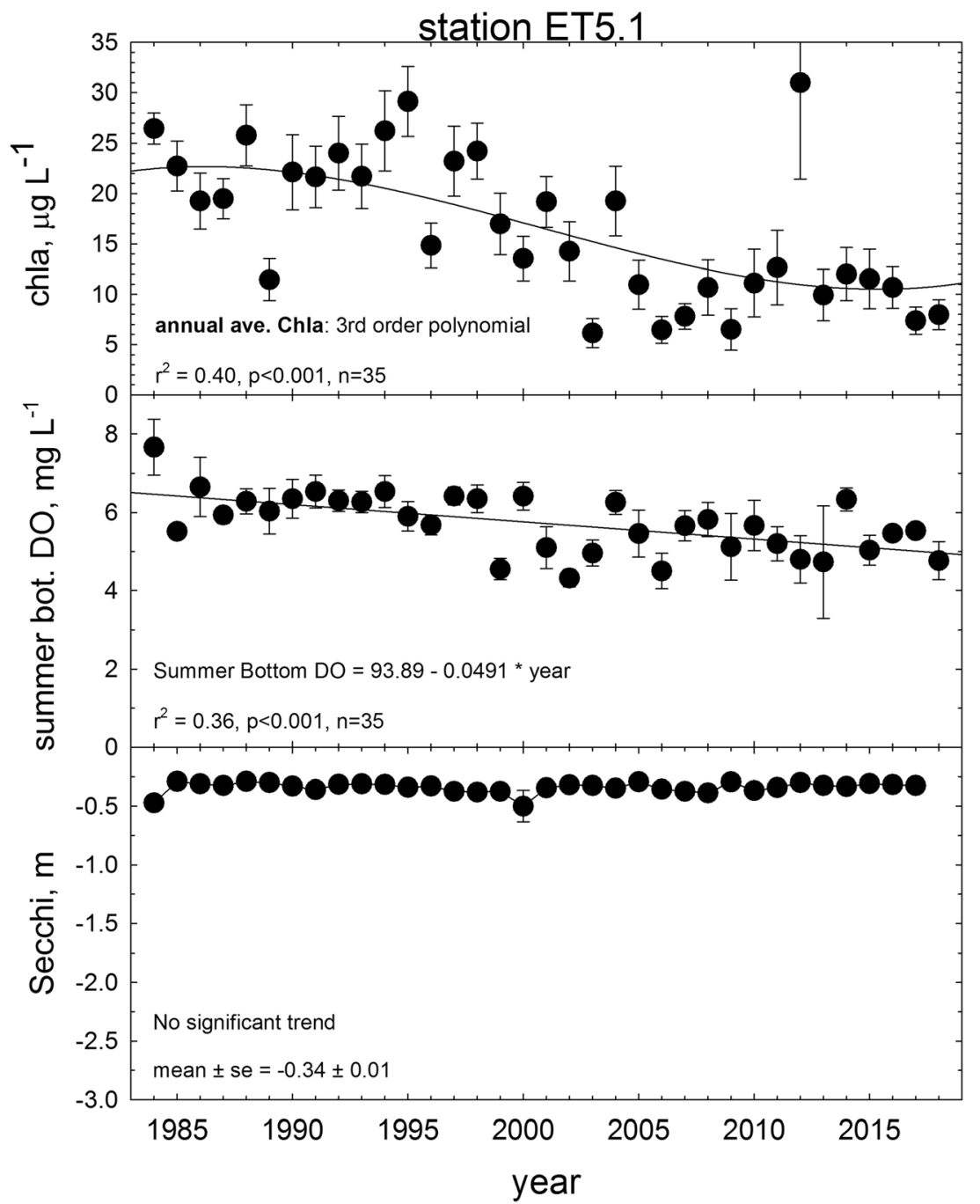


Fig. 7 Trends in annually averaged surface chlorophyll $a$, July-Sept bottom-dissolved oxygen and annual average Secchi depth at the inner mesohaline station ET5.2 near the chlorophyll maximum in the Choptank estuary. Data source: MD DNR

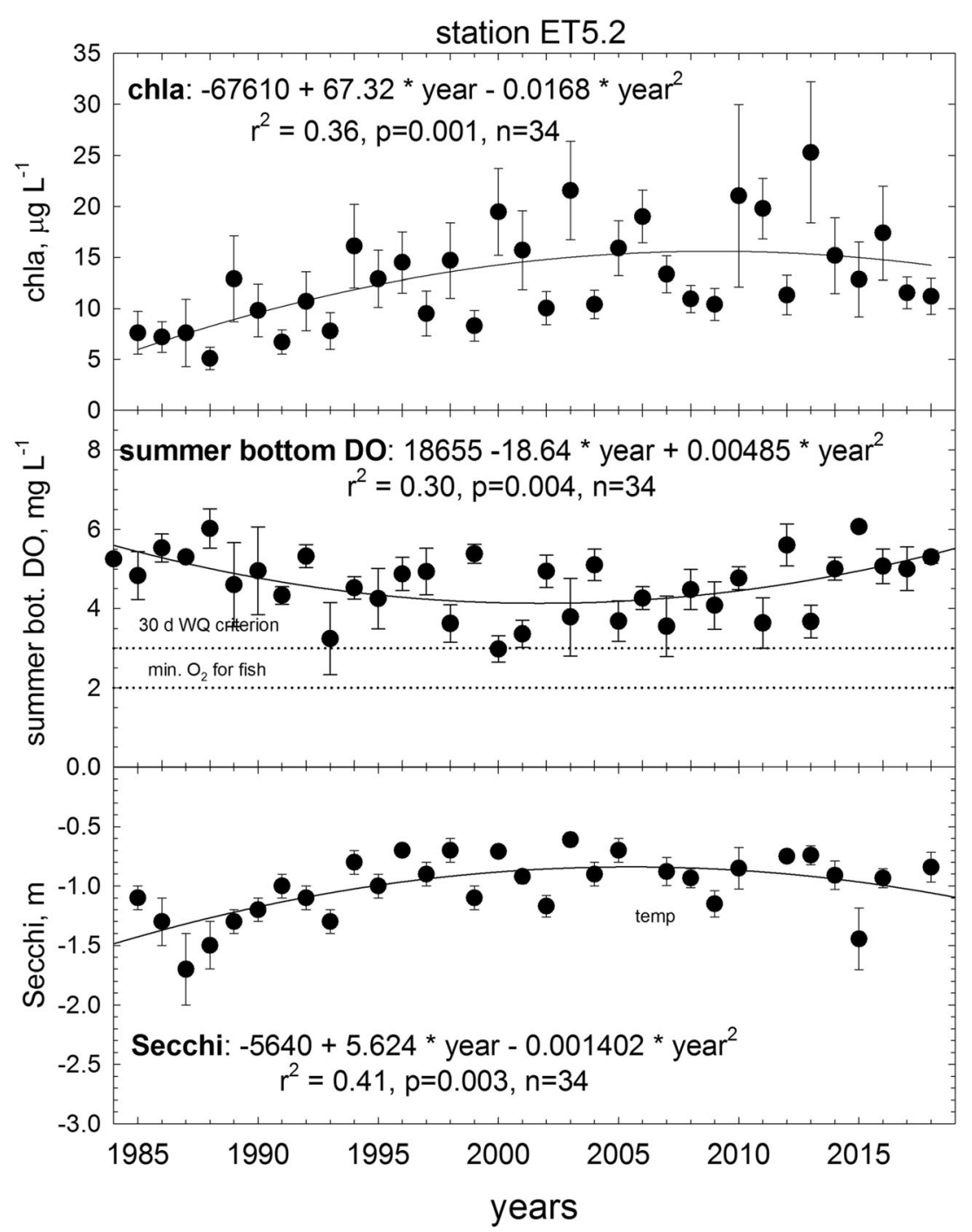

Eshleman et al. 2013; Lloret and Valiela 2016; Detenbeck et al. 2019) as a result of the Clean Air Act (Sullivan et al. 2018). In Europe, similar rates of decline in atmospheric $\mathrm{N}$ deposition have occurred due to legislation, but the current European deposition rates are much higher (10-50 kg N ha $^{-1}$ year $^{-1}$; Dirnböck et al. 2018) than in the USA.

Terrestrial diffuse sources, primarily agriculture, were the largest inputs of both $\mathrm{N}$ and $\mathrm{P}$ to the Choptank estuary. Unlike atmospheric deposition, terrestrial diffuse inputs of $\mathrm{N}$ and $\mathrm{P}$ increased between 1998 and 2017. The increases in agricultural $\mathrm{N}$ and $\mathrm{P}$ export coefficients are consistent with the increasing concentration trends at the USGS Greensboro station (Figs. 3 and 4) and also support the corrections based on Koskelo et al. (2018) that we applied for storm flows. Storm contributions to the estimates of $\mathrm{N}$ and $\mathrm{P}$ inputs in the earlier time period reported by Lee et al. (2001) were not available, and our inclusion of storm effects partially contributes to the differences between the two reference years. However, the changes reported in Table 3 (63 and 134\% for $\mathrm{N}$ and $\mathrm{P}$, respectively) are larger than the additions from stormflows (14\% and 64\%). There was large spatial variability in the trends within the monitored areas of the Choptank, and our smaller agricultural watersheds integrate less area $\left(8-51 \mathrm{~km}^{2}\right.$, Table 1) and illustrate variability at spatial scales smaller than the USGS Greensboro station $\left(294 \mathrm{~km}^{2}\right)$.

Increasing concentrations of $\mathrm{N}$ and $\mathrm{P}$ in agricultural areas have been commonly reported. For example, similar increases in baseflow $\mathrm{N}$ have been observed in the Mississippi River, despite application of agricultural conservation efforts, and reductions in dead zones in the Gulf of Mexico may take decades due to large stores of legacy $\mathrm{N}$ and $\mathrm{P}$ in soils and groundwater (van Meter et al. 2018; Stackpoole et al. 2019). Similarly, the River Seine in France has a history of increases in agricultural $\mathrm{N}$ inputs due to agricultural intensification since the 1950s (Billen et al. 2001; Romero et al. 2016).

Tertiary treatment of urban point sources in the Choptank resulted in large decreases in $\mathrm{N}(-78 \%)$ and $\mathrm{P}(-91 \%)$ in WWTP discharges to mesohaline areas (Fig. 5; Table 2). 
Fig. 8 Trends in annually averaged surface chlorophyll $a$, July-Sept bottom-dissolved oxygen and annual average Secchi depth at the outer mesohaline station EE2.1 in the Choptank estuary near the main axis of Chesapeake Bay. Data source: MD DNR

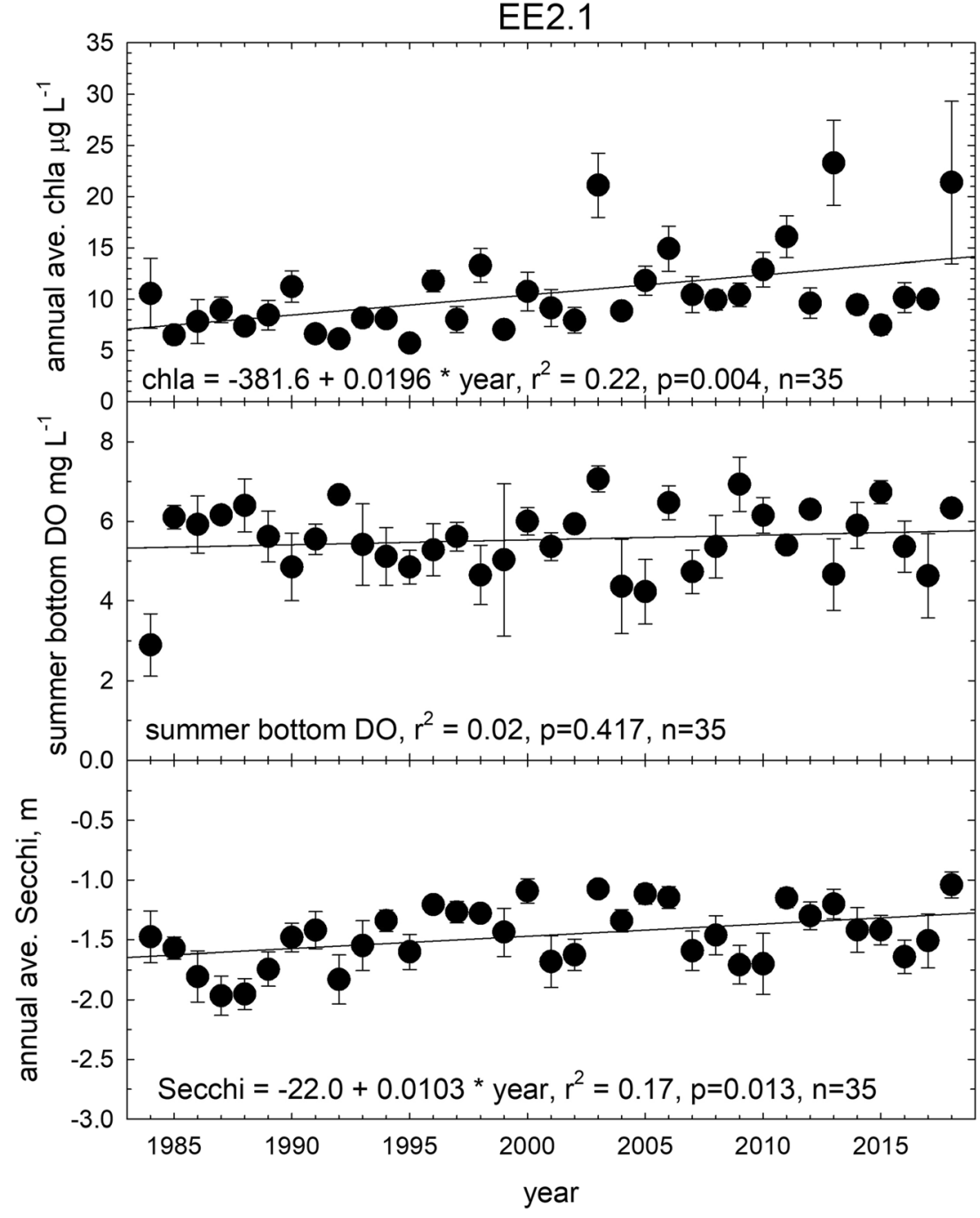

These large changes appear to have influenced water quality at the ET5.2 estuarine monitoring station. Prior to 2000, annual average surface chlorophyll $a$ was increasing and summer bottom dissolved $\mathrm{O}_{2}$ was decreasing, clear symptoms of increasing eutrophication. As wastewater inputs declined due to upgrades to tertiary treatment after 2000 (Fig. 5), the water quality of the Choptank estuary at station ET5.2 improved (Fig. 7). This station is $<2 \mathrm{~km}$ downstream from the Cambridge MD WWTP, the largest in the Choptank. Improvements in estuarine water quality occurred at ET5.2 despite overall increases in $\mathrm{N}$ and $\mathrm{P}$ inputs to the estuary (Table 3).

Unlike estuarine monitoring station ET5.2, ET5.1, and EE2.1 showed decreasing water quality. Water quality at ET5.1, upstream of ET5.2 and primarily upstream of the wastewater inputs, showed a mixed pattern of water quality responses (decreasing chlorophyll $a$, no change in Secchi depth, and decreasing summer bottom dissolved oxygen to under-saturated concentrations; Fig. 6). Since water depth at ET5.1 is $\sim 10 \mathrm{~m}$ and vertically unstratified (Berndt 1999), the shallow Secchi depth of $0.3 \mathrm{~m}$ (indicative of poor water transparency) reflects high turbidity and low light availability in most of the water column. The declining chlorophyll $a$ and summer bottom dissolved $\mathrm{O}_{2}$ indicate increasing heterotrophy at this station. At the most saline estuarine station EE2.1, downstream of ET5.2 and strongly influenced by exchange with Chesapeake Bay, chlorophyll $a$ increased as Secchi depth decreased, but with no trends in summer bottom $\mathrm{O}_{2}$, which were close to atmospheric equilibrium (Fig. 8). The data from this station is consistent with our input budgets showing increasing $\mathrm{N}$ and $\mathrm{P}$ moving from the Choptank watershed into the estuary (Table 3 ).

These three stations (Table 4; Figs. 6, 7 and 8) portray gradients of water quality in the Choptank estuary. At the freshwater end there are high chlorophyll $a$ and nutrients indicative of local watershed nutrient sources (Table 4). Moving into the mesohaline stations, $\mathrm{N}$ and $\mathrm{P}$ concentrations are diluted by water from Chesapeake Bay with lower concentrations of $\mathrm{N}$ and $\mathrm{P}$, and only station ET5.2, in close proximity to the Cambridge WWTP, shows signs of improving water quality. 
The nutrient gradients of $\mathrm{N}$ and $\mathrm{P}$ across these stations are indicative of net movements of $\mathrm{N}$ and $\mathrm{P}$ downstream through the Choptank estuary into the Chesapeake Bay.

Reductions in atmospheric deposition and wastewater discharge occurred a few years prior to improvements in estuarine water quality at ET5.2 (Figs. 2, 5, and 7). This sequence of events and the proximity of ET5.2 to the Cambridge WWTP (Table 2), suggest that reductions in atmospheric N deposition and wastewater $\mathrm{N}$ and $\mathrm{P}$ discharges are responsible for the improving estuarine water quality at ET5.2. This indicates that the investments in mitigating $\mathrm{N}$ emissions to the atmosphere and decreasing $\mathrm{N}$ and $\mathrm{P}$ discharges by upgrading to tertiary treatment at local wastewater plants were responsible for the improvements in estuarine water quality at ET5.2 (Fig. 7). However, we cannot eliminate the influence of augmented estuarine filter feeders such as zooplankton and oyster populations (Bricker et al. 2020, https://www. chesapeakeprogress.com/abundant-life/oysters) or other restoration efforts that occurred in the estuary. Some quantitative estimates on removal of $\mathrm{N}$ and $\mathrm{P}$ by filter feeders is available (e.g., Newell et al. 2004), but additional research would be useful. Regardless of the cause of the improving water quality at ET5.2, Millette et al. (2019) have proposed using rates of increases in chlorophyll $a$, such as the increases during 1985-2000 at ET5.2 (Fig. 7), to target areas for nutrient reduction, and the subsequent improvements in water quality which we observed at ET5.2 support this.

The proximity of the Cambridge WWTP to ET5.2 makes this station particularly sensitive to changes in inputs from municipal wastewater. It is likely that the changes at ET5.2 are a local response to reduced WWTP inputs. Furthermore, unmeasured sources downstream of ET5.2 or occasional Chesapeake Bay inputs (Sanford and Boicourt 1990) could be responsible for increasing chlorophyll $a$ and decreasing Secchi at EE2.1. Most agricultural inputs are upstream of EE2.1, along with most of the drainage basin, but two small wastewater treatment plants are close to EE2.1 (Fig. 1). However, the major gradient of $\mathrm{N}$ and $\mathrm{P}$ concentrations is from freshwater to the Bay (Table 4). We do not have enough information to understand the differences between the interannual variations in water quality at stations EE2.1 and ET5.2, and this is clearly an important area for future research in the Choptank.

Similar effects of reductions in WWTP N and P have been observed throughout other eutrophic estuarine and coastal areas. Examples include the Seine River and estuary (France, Billen et al. 2001), Roskilde Fjord (Denmark, Staehr et al. 2017), Tampa Bay (USA, Johansson and Lewis III 1992), Gunston Cove (Potomac River USA, Jones 2020), the Bilbao estuary (Spain, Garcia-Barcina et al. 2006), and the Avon-Heathcote estuary (New Zealand, Barr et al. 2020; Zeldis et al. 2020). However, in the Stockholm inner archipelago of the Baltic Sea, reductions in WWTP P inputs were buffered by internal recycling from sediments (Walve et al. 2018). In a review by Boesch (2019), quick improvements in estuarine water quality usually resulted from mandated wastewater treatment plant upgrades, with smaller or no reductions from terrestrial diffuse inputs to eutrophic coastal areas worldwide.

The spatial and temporal characteristics of the three estuarine stations in the Choptank are consistent with the conceptual model of estuarine biogeochemical structure proposed by Fisher et al. (1988). Station ET5.1 lies in or near the turbidity maximum of the Choptank estuary where fresh and salt water first mix. The station is $\sim 10 \mathrm{~m}$ deep, with no salinity stratification (Berndt 1999), quite turbid (indicated by the shallow Secchi depth in Fig. 6), with $\mathrm{N}$ and $\mathrm{P}$ concentrations higher than those at the USGS Greensboro station (Fig. 1; Table 4). This indicates additional sources of $\mathrm{N}$ and $\mathrm{P}$ in the watershed between the USGS Greensboro station and ET5.1, and we suggest that the source is likely agricultural areas between the two monitoring stations. Although declining chlorophyll $a$ at ET5.1 can be viewed as indicative of improving water quality, it is more likely due to light limitation of phytoplankton growth under turbid, nutrient-rich conditions (Table 4; Fisher et al. 1999).

Estuarine station ET5.2 has much lower concentrations of $\mathrm{N}$ and P compared to tidal fresh station ET5.1 (Table 4). Between these stations, the Choptank River is sinuous with large areas of oligohaline wetlands (Fig. 1), and we suggest that these wetlands are an important landscape sink within the Choptank basin for upstream N, P, and sediment. Sixty percent of the agricultural diffuse sources are upstream of these wetlands (Table 4), which have been shown to have high rates of denitrification and burial of $\mathrm{N}$ and $\mathrm{P}$ both in the Choptank (Malone et al. 2003) and the Patuxent tributaries of Chesapeake Bay (Jordan et al. 2003; Boynton et al. 2008). This feature of the geomorphology of the estuarine tributaries of Chesapeake Bay may capture a significant fraction of terrestrial inputs from upstream agricultural sources. We have no direct quantification of the potential effects of the oligohaline wetlands lying between ET5.1 and ET5.2, and we suggest that this is a fruitful area for future research efforts in the Choptank and elsewhere.

In contrast to ET5.1, station ET5.2 lies near the chlorophyll maximum of the Choptank estuary (Berndt 1999). The chlorophyll maximum is a mesohaline region of estuaries where salinity stratification limits the depth of mixing and turbidity decreases, enabling phytoplankton in surface waters to access sufficient light to accumulate biomass using the abundant nutrient supplies from upstream or local sources (Fisher et al. 1988). While the location and size of the turbidity and chlorophyll maxima can shift up or downstream with river discharge (Fisher et al. 1988; Berndt 1999), ET5.2 appears to be a sensitive, well-placed station to indicate the collective effects of 
upstream, non-tidal, nutrient inputs, apparent modulation of those inputs by oligohaline marshes, and local, more downstream WWTP inputs.

An interesting question is why there is improving water quality at ET5.2 despite an overall increase in N and P inputs to the estuary as a whole. This response suggests that local actions matter; in this case greatly reducing local inputs from the largest WWTP improved adjacent estuarine water quality, even when the overall estuary was receiving more $\mathrm{N}$ and $\mathrm{P}$. It is possible that other local water quality improvements occurred unrecorded near other waste water plants.

There are also other interpretations of the results reported here. The increasing chlorophyll $a$ and decreasing Secchi depth at downstream station EE2.1 may have been due to unmeasured nutrient sources downstream of ET5.2 or tidal exchange with Chesapeake Bay. However, the major gradient of $\mathrm{N}$ and $\mathrm{P}$ concentrations is from freshwater to the Bay indicative of the importance of terrestrial nutrient sources (Table 4). Most agricultural inputs are upstream of EE2.1, along with most of the drainage basin, but two small wastewater treatment plants are close to EE2.1 (Trappe and Oxford; Table 2; Fig. 1). Although Trappe is a small plant, it only had secondary treatment during this period of record and is the third largest source of WWTP N. We do not have enough information to understand the differences between the interannual variations in water quality at stations EE2.1 and ET5.2, and this is clearly an important area for future research.

\section{Test of the Hypothesis}

The data presented provide partial support for our hypothesis that management efforts to reduce inputs from the three known nutrient sources in the Choptank watershed (agriculture, wastewater, atmospheric deposition) have improved water quality in the Choptank estuary. Both atmospheric deposition and WWTP inputs declined due to management actions, whereas overall inputs increased due to higher agricultural inputs, despite conservation efforts. An important question to explore is why efforts to reduce agricultural diffuse sources have not provided reductions in $\mathrm{N}$ and $\mathrm{P}$ inputs to the Choptank estuary. Many agricultural BMPs have been applied throughout the Choptank watershed (Staver and Brinsfield 2001), and many BMPs have been found within agricultural watersheds that we monitor (Fox et al. n.d.). There is a similar report by Kroon et al. (2016) on the lack of effectiveness of agricultural conservation actions in areas contributing to declining water quality near the Great Barrier Reef in Australia.

There are several potential explanations for the lack of an agricultural contribution to the improving water quality in the Choptank estuary. First, municipal WWTP are single entities funded by tax payers and subject to government regulations (NPDES) that are assessed through self-monitored data submitted to the US EPA (e.g., Fig. 5). In contrast, farmers are private business owners with a range of attitudes concerning voluntary conservation practices (Smith et al. 2007; van Grieken et al. 2019; Fox et al. n.d.). There is no routine monitoring of groundwater or surface discharges from farms with BMPs except for research projects such as this one or nonprofit water quality organizations. This situation provides little incentive or feedback to farmers on voluntary BMP applications. Since at least some costs of the BMPs fall on the individual farmer, some hesitate to apply BMPs or apply additional BMPs because of the time and expense (Fox et al. n.d.). Cary and Roberts (2011) noted similar reservations by Australian farmers to adopt BMPs.

Second, there are time lags of years in the delivery of groundwater to streams (e.g., Meals et al. 2010; Sanford and Pope 2013). For example, median groundwater ages of 5-10 years have been reported in Choptank watersheds (Sutton et al. 2009). However, groundwater nitrate concentrations can be altered significantly in short time periods. BunnellYoung et al. (2017) showed reductions in groundwater nitrate from $\sim 700 \mu \mathrm{M}\left(9.8 \mathrm{mg} \mathrm{N} \mathrm{L}^{-1}\right)$ to $\sim 70 \mu \mathrm{M}\left(0.98 \mathrm{mg} \mathrm{N} \mathrm{L}^{-1}\right)$ in the surface unconfined aquifer over $2-3$ years after fields with grain production (corn-wheat-soy) were converted to unfertilized conservation lands in the Choptank Basin. However, this lower nitrate groundwater must be transported to a stream before we detect the impacts of positive agricultural management. It is possible that the small decreases in the baseflow TN of the agricultural watersheds reported in Table 1 are due to the slow emergence of groundwater with lower nitrate concentrations that are appearing as a result of conservation efforts that occurred 5-10 years ago. However, our widespread measurements of groundwater nitrate under agricultural fields with BMPs do not show systematic decreases in N concentrations (Table 1; Fox et al. 2014, n.d.).

Last, insufficient density, extent, and poor placement of voluntary conservation practices might be responsible for the lack of agricultural contribution to improving Choptank water quality. In active agricultural fields, current nitrate levels in groundwater are high (300-1200 $\mu \mathrm{M}, 4-17 \mathrm{mg} \mathrm{NO}_{3}-\mathrm{N} \mathrm{L}^{-1}$, Fox et al. 2014, n.d.), similar to or higher than in streams draining mixed land uses (Figs. 3 and 4). In addition, agricultural soils typically have high $\mathrm{P}$ levels greatly exceeding crop needs (100-400 mg P kg-1; Sims et al. 2002; Fisher et al. 2018). These legacy nutrients will continue to deliver large quantities of $\mathrm{N}$ and $\mathrm{P}$ to downstream receiving waters such as the Choptank estuary until soil and groundwater $\mathrm{N}$ and $\mathrm{P}$ concentrations are reduced by more technical assistance and outreach to farmers on BMPs (Lemke et al. 2010). One possible solution to reduce the high concentrations in waters draining agricultural areas is a more systematic application of BMPs with follow-up monitoring of conservation effects to validate the expectations of BMP impacts (Lemke et al. 2011). 
There is strong economic pressure on farmers to improve crop yields, regardless of low $\mathrm{N}$ and $\mathrm{P}$ use efficiency (Cassman et al. 2002). This economic pressure could be countered by equivalent economic pressure for good performance of conservation efforts (Winsten 2009; Winsten and Hunter 2011; van Grieken et al. 2019). Market or other financial rewards for validated conservation management could potentially result in more dense applications of BMPs and significant reductions in $\mathrm{N}$ and $\mathrm{P}$ losses from agricultural areas (Liu et al. 2018). This approach will require involvement of all stakeholders, including the broad range of food and feed producers, in order to balance the economic viability of agriculture and its impact on the environment.

Improvements in water quality have occurred in the middle of the Choptank estuary (Figs. 1 and 7). This appears to be due primarily to public tax investments and government regulations to reduce atmospheric deposition (Clean Air Act) and WWTP discharges (Chesapeake Bay Restoration Act). However, we have not yet detected evidence of systematic reductions in agricultural $\mathrm{N}$ and $\mathrm{P}$ inputs, although we did measure some reductions in $\mathrm{N}$ and $\mathrm{P}$ from some smaller, agricultural watersheds (Fig. 4; Table 1). If reductions in agricultural $\mathrm{N}$ and $\mathrm{P}$ inputs over broad areas do occur in the future, improvements in estuarine water quality larger than those reported here, and more consistently throughout the entire estuary, could be expected. For this reason, it is important to continue monitoring agricultural areas with enhanced management practices. Direct measurements are needed to evaluate whether reduced concentrations of $\mathrm{N}$ and $\mathrm{P}$ are occurring in groundwater and soils of areas with BMPs or whether inefficient or insufficient management practices have been implemented to make significant reductions in losses of $\mathrm{N}$ and $\mathrm{P}$ from agricultural fields.

\section{Conclusions}

The Choptank basin is $1756 \mathrm{~km}^{2}$ of land draining to $280 \mathrm{~km}^{2}$ of an estuarine tributary of the Chesapeake Bay. There are strong similarities between the Choptank basin and the Chesapeake as a whole, which enables the Choptank to be used as a model for progress in the Chesapeake. We updated an $\mathrm{N}$ and $\mathrm{P}$ input budget for the Choptank estuary previously constructed for reference year 1998 to evaluate progress towards water quality goals in reference year 2017. We found decreases in atmospheric $\mathrm{N}$ deposition and human wastewater inputs, but overall increases in agricultural $\mathrm{N}$ and $\mathrm{P}$ inputs, the largest contributor. Despite the lack of widespread reductions in agricultural $\mathrm{N}$ and $\mathrm{P}$, we found local improvements at some small agricultural watersheds and at an estuarine station. The estuarine station is near a large WWTP outfall, and improvements in water quality occurred following reductions in wastewater and atmospheric $\mathrm{N}$ and $\mathrm{P}$ inputs from public investments in clean air and WWTP upgrades. While these local effects are encouraging, it is important to continue to improve agricultural practices to reduce losses of $\mathrm{N}$ and $\mathrm{P}$ from farms. Even greater improvements in estuarine water quality throughout the estuary could be expected following reductions from this largest source of $\mathrm{N}$ and $\mathrm{P}$.

Acknowledgments The MD Dept. of Natural Resources, the US Geological Survey, US National Atmospheric Deposition Program, and the EPA Chesapeake Bay Program provided access to data on estuarine water quality, stream flow and chemistry, rain quantity and chemistry, and WWTP discharge and chemistry, respectively. We thank Gary Shenk for assistance in accessing CAST data, Michael Mallonee for assistance in using CIMS, wastewater treatment personnel for access to plants and for sharing data, and the HPL Analytical Services Laboratory for timely and accurate analyses.

Funding Funding for the long-term watershed monitoring and data analysis has been provided by USDA (CEAP Program 2004, CSREES 2005 03892) and NSF (Ecosystem Studies Program 09-19181, 12-52923, and 13-25553).

Open Access This article is licensed under a Creative Commons Attribution 4.0 International License, which permits use, sharing, adaptation, distribution and reproduction in any medium or format, as long as you give appropriate credit to the original author(s) and the source, provide a link to the Creative Commons licence, and indicate if changes were made. The images or other third party material in this article are included in the article's Creative Commons licence, unless indicated otherwise in a credit line to the material. If material is not included in the article's Creative Commons licence and your intended use is not permitted by statutory regulation or exceeds the permitted use, you will need to obtain permission directly from the copyright holder. To view a copy of this licence, visit http://creativecommons.org/licenses/by/4.0/.

\section{References}

Akaike, H. 1973. Information theory as an extension of the maximum likelihood principle. In Second International Symposium on Information Theory, ed. B.N. Petroy and F. Csaki, 267-281. Budapest: Akademiai Kiado.

Alexander, R.B., P.J. Johnes, E.W. Boyer, and R.A. Smith. 2002. A comparison of models for estimating the riverine export of nitrogen from large watersheds. Biogeochem 57/58: 295-339.

Ator, S.W., A.M. Garcia, G.E. Schwarz, J.D. Blomquist, and A.J. Sekellick. 2019. Toward explaining nitrogen and phosphorus trends in Chesapeake Bay Tributaries, 1992-2012. JAWRA. 55 (5): 1149 1168. https://doi.org/10.1111/1752-1688.12756.

Barr, N., J. Weldis, K. Scheuer, and D. Schiel. 2020. Macroalgal bioindicators of recovery from eutrophication in a tidal lagoon following wastewater diversion and earthquake disturbance. Estuaries and Coasts 43 (2): 240-255.

Beaulac, M.N., and K.H. Reckhow. 1982. An examination of land use nutrient export relationships. Water Resources Bulletin 18 (6): $1013-1024$.

Benitez, J.A., and T.R. Fisher. 2004. Historical land cover conversion (1665-1850) in the Choptank watershed, Eastern USA. Ecosystems 7: 219-232.

Berndt, H. (1999). Effects of nutrients and turbidity from point and nonpoint source inputs on phytoplankton in the Choptank estuary. MS thesis, Univ. of MD, 168 pps. 
Billen, G., J. Garnier, A. Ficht, and C. Cun. 2001. Modeling the response of water quality in the Seine river estuary to human activity in its watershed over the last 50 years. Estuaries 24 (6): 977-993.

Boesch, D.F. 2019. Barriers and bridges in abating coastal eutrophication. Frontiers in Marine Science 6: 123. https://doi.org/10.3389/fmars. 2019.00123.

Boynton, W.R., J.D. Hagy, J.C. Cornwell, W.M. Kemp, S.M. Greene, M.S. Owens, J.E. Baker, and R.K. Larsen. 2008. Nutrient budgets and management actions in the Patuxent River Estuary, Maryland. Estuaries and Coasts 32: 623-651.

Bricker, S.B., K.C. Rice, and O.P. Bricker III. 2014. From headwaters to coast: Influence of human activities on water quality of the Potomac River estuary. Aquatic Geochemistry 20 (2-3): 291-323.

Bricker, S.B., R.E. Grizzle, P. Trowbridge, J.M. Rose, J.G. Ferreira, K. Wellman, C. Zhu, E. Galimany, G.H. Wikfors, C. Saurel, R.L. Miller, J. Wands, R. Rheault, J. Steinberg, A.P. Jacob, E.D. Davenport, S. Ayvazian, M. Chintala, and M.A. Tedesco. 2020. Bioextractive removal of nitrogen by oysters in Great Bay Piscataqua River estuary, New Hampshire, USA. Estuaries and Coasts 43: 23-38.

Bunnell-Young, D., T. Rosen, T.R. Fisher, T. Moorshead, and D. Koslow. 2017. Dynamics of nitrate and methane in shallow groundwater following land use conversion from agricultural grain production to conservation easement. Agriculture, Ecosystems \& Environment 248: 200-214.

Burnham, K.P., and D.R. Anderson. 2002. Model selection and multimodel inference: A practical information-theoretic approach. second ed. New York: Springer-Verlag 70 pp.

Carlozo, N., G. Radcliffe, and T. R. Fisher. 2008. Trends in water quality in response to human populations and land use in the Delaware, Hudson, and Chesapeake Basins. Abstract, ASLO, Mar. 2008, Orlando FL.

Cary, J., and A. Roberts. 2011. The limitations of environmental management systems in Australian agriculture. Journal of Environmental Management 92 (3): 878-885.

Cassman, K.G., A. Dobermann, and D.T. Walters. 2002. Agroecosystems, nitrogen-use efficiency, and nitrogen management. Ambio 31 (2): 132-140.

CAST. 2017. Chesapeake area scenario tool. http://cast.chesapeakebay. net/. Accessed Nov 2019.

Ches. 2019. Bay Found. https://www.cbf.org/issues/agriculture/bestmanagement-practices.html. Accessed Jan 2020.

Clark, G.M., D.K.I. Mueller, and M.A. Mast. 2000. Nutrient concentrations and yields in undeveloped stream basins of the United States. Journal of the American Water Resources Association 36 (4): 849 860.

Clesceri, N.L., S.J. Curran, and R.I. Sedlak. 1986. Nutrient loads to Wisconsin lakes. Part. 1. Nitrogen and phosphorus export coefficients. Water Resources Bulletin 22 (6): 983-990.

Cooper, S.R., and G.S. Brush. 1993. A 2,500 year history of anoxia and eutrophication in Chesapeake Bay. Estuaries 16 (3): 617-626.

Dagg, M.J., and G.A. Breed. 2003. Biological effects of Mississippi River nitrogen on the northern Gulf of Mexico - a review and synthesis. Journal of Marine Systems 43 (3-4): 133-152.

David, M.B., L.E. Gentry, D.A. Kovacic, and K.M. Smith. 1997. Nitrogen balance in and export from an agricultural watershed. Journal of Environmental Quality 26 (4): 1038-1048.

Davis, F.W. 1985. Historical changes in submerged macrophyte communities of upper Chesapeake Bay. Ecology 66 (3): 981-993.

Deegan, L.A., D.S. Johnson, R.S. Warren, B.J. Peterson, J.W. Fleeger, S. Fagherazzi, and W.M. Wollheim. 2012. Coastal eutrophication as a driver of salt marsh loss. Nature 490 (7420): 388-392.

Detenbeck, N.W., M. You, and D. Torre. 2019. Recent changes in nitrogen sources and load components to estuaries of the contiguous United States. Estuaries and Coasts 42: 2096-2113.
Dirnböck, T., G. Pröll, K. Austnes, J. Beloica, B. Beudert, R. Canullo, A. De Marco, M.F. Fornasier, M. Futter, K. Goergen, U. Grandin, M. Holmberg, A.-J. Lindroos, M. Mirtl, J. Neirynck, T. Pecka, T.M. Nieminen, J.-F. Nordbakken, M. Posch, G.-J. Reinds, E.C. Rowe, M. Salemaa, T. Scheuschner, F. Starlinger, A.K. Uzięblo, S. Valinia, J. Weldon, W.G.W. Wamelink, and M. Forsius. 2018. Currently legislated decreases in nitrogen deposition will yield only limited plant species recovery in European forests. Environmental Research Letters 13 (12): 125010.

EPA. 2010. https://www.epa.gov/chesapeake-bay-tmdl/chesapeake-baytmdl-document. Accessed Jan 2020.

EPA. 2016. https://www.epa.gov/sites/production/files/2016-06/ documents/wastewater progress report 06142016.pdf. Accessed Dec 2018.

EPA. 2017. https://www.epa.gov/chesapeake-bay-tmdl/chesapeake-baywatershed-implementation-plans-wips. Accessed Jan 2020.

EPA. 2018. https://www.chesapeakebay.net/what/programs_projects. Accessed Jan 2020.

Eshleman, K.N., R.D. Sabo, and K.M. Kline. 2013. Surface water quality in improving due to declining atmospheric $\mathrm{N}$ deposition. Environmental Science \& Technology 47 (21): 12193-12200.

Fisher, T.R., L.W. Harding, D.W. Stanley, and L.G. Ward. 1988. Phytoplankton, nutrients, and turbidity in the Chesapeake, Delaware, and Hudson River estuaries. Estuarine, Coastal and Shelf Science 27 (1): 61-93.

Fisher, T.R., K.-Y. Lee, H. Berndt, J.A. Benitez, and M.M. Norton. 1998. Hydrology and chemistry of the Choptank River basin in the Chesapeake Bay drainage. Water, Air, and Soil Pollution 105 (1/2): 387-397.

Fisher, T.R., A.B. Gustafson, K. Sellner, R. Lacuture, L.W. Haas, R. Magnien, R. Karrh, and B. Michael. 1999. Spatial and temporal variation in resource limitation in Chesapeake Bay. Marine Biology 133 (4): 763-778.

Fisher, T.R., J.D. Hagy III, W.R. Boynton, and M.R. Williams. 2006a. Cultural eutrophication in the Choptank and Patuxent estuaries of Chesapeake Bay. Limnology and Oceanography 51 (1part2): 435447.

Fisher, T.R., J.A. Benitez, K.-Y. Lee, and A.J. Sutton. 2006b. History of land cover change and biogeochemical impacts in the Choptank River basin in the mid-Atlantic region of the US. International Journal of Remote Sensing 27 (17): 3683-3703.

Fisher, T. R., T. E. Jordan, K. W. Staver, A. B. Gustafson, A. I. Koskelo, R. J. Fox, A. J. Sutton, T. Kana, K. A. Beckert, J. P. Stone, G. McCarty, and M. Lang. 2010. The Choptank Basin in transition: Intensifying agriculture, slow urbanization, and estuarine eutrophication, pps. 135-165, IN: M. J. Kennish and H. W. Paerl (eds), Coastal Lagoons: Systems of Natural and Anthropogenic Change, CRC Press.

Fisher, T.R., R.J. Fox, A.B. Gustafson, J. Lewis, N. Millar, and J. Winsten. 2018. Fluxes of nitrous oxide and nitrate from agricultural fields on the Delmarva Peninsula: N biogeochemistry and economics of field management. Agriculture, Ecosystems and Environment 254: $162-178$.

Follett, J.R., and R.F. Follett. 2001. Utilization and metabolism of nitrogen by humans. In Nitrogen in the environment: Sources, problems and management, ed. R. Follett and J.L. Hatfield, 65-92. New York: Elsevier Science.

Fox, R.J., T.R. Fisher, A.B. Gustafson, T.E. Jordan, T.M. Kana, and M.W. Lang. 2014. Searching for the missing nitrogen: Biogenic nitrogen gases in groundwater and streams. The Journal of Agricultural Science 152: S96-S106.

Fox, R. J., T. R. Fisher, A. B. Gustafson, E. L. Koontz, M. Lepori-Bui, K. L. Kvalnes, D. Bunnell-Young, J. R. Gardner, J. Lewis, J. Winsten, and K. A. Fisher. n.d. Sub. An evaluation of untargeted BMP management to improve water quality in small agricultural watersheds. Journal of Environmental Management. (in review). 
Garcia-Barcina, J.M., J.A. Conzález-Oreja, and A. De la Sota. 2006. Assessing the improvement of the Bilbao estuary water quality in response to pollution abatement measures. Water Research 40 (5): 951-960.

Glibert, P.M., D.J. Conley, T.R. Fisher, L.W. Harding Jr., and T.C. Malone. 1995. Dynamics of the 1990 winter/spring bloom in Chesapeake Bay. Marine Ecology Progress Series 122: 27-43.

Groffman, P.M., D.J. Bain, L.E. Band, K.T. Belt, G.S. Brush, J.M. Grove, R.V. Pouyat, I.C. Yesilonis, and W.C. Zipperer. 2003. Down by the riverside: Urban riparian ecology. Frontiers in Ecology and the Environment 1 (6): 315-321.

Gurbisz, C., W.M. Kemp, L.P. Sandord, and R.J. Orth. 2016. Mechanisms of storm-related loss and resilience in a large submersed plant bed. Estuaries and Coasts 39 (4): 951-966.

Hagy, J.D., W.R. Boynton, C.W. Keefe, and K.V. Wood. 2004. Hypoxia in Chesapeake Bay, 1950-2001: Long-term change in relation to nutrient loading and river flow. Estuaries 27 (4): 634-658.

Harding, L.W., Jr., and E.S. Perry. 1997. Long-term increase of phytoplankton biomass in Chesapeake Bay. 1950-1994. Marine Ecology Progress Series 157: 39-52.

Harding, L.W., Jr., R.A. Batiuk, T.R. Fisher, C.L. Gallegos, T.C. Malone, W.D. Miller, M.R. Mulholland, H.W. Paerl, E.S. Perry, and P. Tango. 2014. Scientific Bases for Numerical Chlorophyll Criteria in Chesapeake Bay. Estuaries and Coasts 37 (1): 134-148.

Harding, L.W., M.E. Mallonee, E.S. Perry, W.D. Miller, J.E. Adolf, C.L. Gallegos, and H.W. Paerl. 2019. Long-term trends, current status, and transitions of water quality in Chesapeake Bay. Nature Scientific Reports 9: 6709. https://doi.org/10.1038/s41598-01943036-6.

Hirsch, R.M., D.L. Moyer, and S.A. Archfield. 2010. Weighted regressions on time, discharge, and season (WRTDS), with an application to Chesapeake Bay river inputs. JAWRA 46: 857-880.

Hively, W. D., O. H. Devereuz, and J. L. D. Keisman. 2018. Agricultural conservation practice implementation in the Chesapeake Bay watershed supported by the US Dept. of Agriculture. US Geol. Data Series 1102 , 46 pps.

Jaworski NA, Romano B, Buchanan C (2007) A treatise. The potomac river basin and its estuary: Landscape loadings and water quality trends 1895-2005. p. 221. Available from the Potomac Integrative Analysis Online Collection at https://www.potomacriver.org.

Johansson, J.O.R., and R.R. Lewis III. 1992. Recent improvements of water quality and biological indicators in Hillsborough Bay, a highly impacted subdivision of Tampa Bay, Florida, USA. Science of the Total Environment Supple. 1992: 1199-1215.

Jones, R.C. 2020. Recovery of a tidal freshwater embayment from eutrophication: A multidecadal study. Estuaries and Coasts 43 (6): 1318 1334. https://doi.org/10.1007/s12237-020-00730-3.

Jordan, T.E., D.E. Weller, and D.L. Correll. 2003. Sources of nutrient inputs to the Patuxent River estuary. Estuaries 26 (2): 226-243.

Kemp, W.M., W.R. Boynton, J.E. Adolf, D.F. Boesch, W.C. Boicourt, G. Brush, J.C. Cornwell, T.R. Fisher, P.M. Glibert, J.D. Hagy, L.W. Harding, E.D. Houde, D.G. Kimmel, W.D. Miller, R.I.E. Newell, M.R. Roman, E.M. Smith, and J.C. Stevenson. 2005. Eutrophication of Chesapeake Bay: Historical trends and ecological interactions. Marine Ecology Progress Series 303: 1-29.

Koskelo, A.I., T.R. Fisher, R. Utz, and T.E. Jordan. 2012. A new precipitation-based method of baseflow separation and event identification for small watersheds $\left(<50 \mathrm{~km}^{2}\right)$. Journal of Hydrology 450-451: 267-278.

Koskelo, A., T.R. Fisher, A.J. Sutton, and A.B. Gustafson. 2018. Biogeochemical storm response in agricultural watersheds of the Choptank River basin, Delmarva Peninsula, USA. Biogeochemistry 139 (3): 215-239.

Kroon, F.J., P. Thorburn, B. Schaffelke, and S. Whitten. 2016. Towards protecting the Great Barrier Reef from land-based pollution. Global Change Biology 22 (6): 1985-2002.
Lee, K.-Y., T.R. Fisher, and E. Rochelle-Newall. 2001. Modeling the hydrochemistry of the Choptank River basin using GWLF and Arc/Info: 2. Model Application. Biogeochemistry 56: 311-348.

Lefcheck, J.S., R.J. Orth, W.C. Dennison, D.J. Wilcox, R.R. Murphy, J. Keisman, C. Gurbisz, M. Hannam, J.B. Landry, K.A. Moore, C.J. Patrick, J. Testa, D.W. Weller, and R.A. Batiuk. 2018. Long-term nutrient reductions lead to the unprecedented recovery of a temperate coastal region. PNAS 10 (107): 1073/1715798115.

Lemke, A.M., T.T. Lindenbaum, W.L. Perry, M.E. Herbert, T.H. Tear, and J.R. Herkert. 2010. Effects of outreach on he awareness and adoption of conservation practices by farmers in two agricultural watersheds of the Mackinaw River, Illinois. Journal of Soil and Water Conservation 65 (5): 304-315.

Lemke, A.M., K.G. Kirkham, T.T. Lindenbaum, M.E. Herbert, T.H. Tear, W.L. Perry, and J.R. Herkert. 2011. Evaluating agricultural best management practices in tile-drained subwatersheds of the Mackinaw River, Illinois. Journal of Environmental Quality 40 (4): 1215-1228.

Liu, Y., B.A. Engel, D.C. Flanagan, M.W. Gitau, S.K. McMillan, and I. Chaubey. 2017. A review on effectiveness of best management practices in improving hydrology and water quality: Needs and opportunities. Science of the Total Environment 601-602: 580-593.

Liu, T., R.J.F. Bruins, and M.T. Heberling. 2018. Factors influencing farmers adoption of best management practices: A review and synthesis. Sustainability 10 (2): 432.

Lloret, J., and I. Valiela. 2016. Unprecedented decrease in deposition of nitrogen oxides over North America: The relative effects of emission controls and prevailing air-mass trajectories. Biogeochem. 129 (1-2): $165-180$

Malone, T., W. Boicourt, J. Cornwell, L. Harding Jr., and J. Stevenson. 2003. The Choptank River: A mid-Chesapeake Bay index site for evaluating ecosystem responses to nutrient management. In Final report to the Coastal Intensive Site Network (CISNet) Horn Point Environmental Laboratory. Cambridge: University of Maryland 64 pp.

McCarty, G.W., L.L. McConnell, C.J. Hapeman, A. Sadeghi, C. Graff, W.D. Hively, M.L. Lang, T.R. Fisher, T. Jordan, C.P. Rice, E.E. Codling, D. Whitall, A. Lynn, J. Keppler, and M.L. Fogel. 2008. Water quality and conservation practice effects in the Choptank River watershed. Journal of Soil and Water Conservation 63 (6): 461-474.

Meals, D.W., S.A. Dressing, and T.E. Davenport. 2010. Lag time in water quality response to best management practices: A review. Journal of Environmental Quality 39 (1): 85-96.

Millette, N.C., C. Kelble, A. Linhos, S. Ashby, and L. Visser. 2019. Using spatial variability in the rate of change of chlorophyll a to improve water quality management in a subtropical oligotrophic estuary. Estuaries and Coasts 42 (7): 1792-1803.

Moyer, D.L. and J. D. Blomquist. 2020. Nitrogen, phosphorus, and suspended-sediment loads and trends measured at the Chesapeake Bay River Input Monitoring stations-Water years 1985-2018: U.S. Geological Survey data release, accessed February 25, 2020, at $10.5066 / \mathrm{P} 9 \mathrm{P} 4 \mathrm{H} 3 \mathrm{ZX}$.

Newell, R.I.E., T.R. Fisher, R.R. Holyoke, and J.C. Cornwell. 2004. Influence of eastern oysters on $\mathrm{N}$ and $\mathrm{P}$ regeneration in Chesapeake Bay, USA. In The comparative roles of suspension feeders in ecosystems, ed. R. Dame and S. Olenin. Kluwer: NATO Science Series: IV - Earth and Environmental Sciences.

Nixon, S.W. 1995. Coastal marine eutrophication: a definition, social causes, and future concerns. Ophelia 41: 199-219.

Officer, C.B., R.B. Biggs, J.L. Taft, L.E. Cronin, M.A. Tyler, and W.R. Boynton. 1984. Chesapeake Bay anoxia: Origin, development, and significance. Science 223 (4631): 22-27.

Orth, R.J., and K.A. Moore. 1983. Chesapeake Bay: An unprecedented decline in submerged aquatic vegetation. Science 222 (4619): 5153. 
Reckhow, K.H., M.N. Beaulac, and J.T. Simpson. 1980. Modeling phosphorus loading and lake response under uncertainty: A manual and compilation of export coefficients. Washington, D.C.: Clean Lakes Section of U.S. E.P.A. EPA 440/5-80-011.

Romero, E., R. Le Gendre, J. Garnier, G. Billen, C. Fisson, M. Silvestre, and P. Riou. 2016. Long-term water quality in the lower Seine: Lessons learned over 4 decades of monitoring Env. Sci Pol 58: 141-154. https://doi.org/10.1016/j.envsci.2016.01.016.

Sanford, L.P., and W.C. Boicourt. 1990. Wind-forced salt intrusion into a tributary estuary. Journal of Geophysical Research, Oceans 95 (C8): 13,357-13,371.

Sanford, W.E., and J.P. Pope. 2013. Quantifying groundwater's role in delaying improvements to Chesapeake Bay water quality. Environmental Science \& Technology. https://doi.org/10.1021/ es401334k.

Schlesinger, W.H., and E. Bernhardt. 2014. Biogeochemistry: An analysis of global change. 3rd ed. Cambridge: Academic Press 688 pp.

Sims, J.T., R.O. Maguire, A.B. Leytem, K.L. Gartley, and M.C. Pautler. 2002. Evaluation of Mehlich 3 as an agri-environmental soil phosphorus test for the Mid-Atlantic United States of America. Soil Science Society of America Journal 66 (6): 2016-2032.

Smith, C.M., J.M. Peterson, and J.C. Leatherman. 2007. Attitudes of Great Plains producers about best management practices, conservation programs, and water quality. Journal of Soil and Water Conservation 62: 97A-103A.

Stackpoole, S.M., E.G. Stetts, and L.A. Sprague. 2019. Variable impacts of contemporary versus legacy agricultural phosphorus on US river water quality. PNAS 116 (41): 20562-20567.

Staehr, P.A., J. Testa, and J. Carstensen. 2017. Decadal changes in water quality and net productivity of a shallow Danish estuary following significant nutrient reductions. Estuaries and Coasts 40 (1): 63-79.

Staver, K. W. and R. B. Brinsfield. 1996. The effect of erosion control practices on phosphorus transport from coastal plain agricultural watersheds. pps. 215-222. In: Toward a sustainable coastal watershed: The Chesapeake Experiment. Proc. Conf. 1-3 June1994. Norfolk, VA, Ches. Res. Consort. Pub. 149.

Staver, K.W., and R.B. Brinsfield. 2001. Agriculture and water quality on the Maryland Eastern Shore: Where do we go from here? BioScience 51 (10): 859-868.

Sullivan, T.J., C.T. Driscoll, C.M. Beier, D. Burtraw, I.J. Fernandez, J.N. Galloway, D.A. Gay, C.L. Goodale, G.E. Likens, G.M. Lovett, and S.A. Watmough. 2018. Air pollution success stories in the United States: The value of long-term observations. Environmental Science \& Policy 84: 69-73.

Sutton, A.J., T.R. Fisher, and A.B. Gustafson. 2009. Historical changes in water quality at German Branch in the Choptank River basin. Water, Air, and Soil Pollution 199 (1-4): 353-369.

van Grieken, M.E., P.C. Roebeling, I.C. Bohnet, S.M. Whitten, A.J. Webster, M. Poggio, and D. Pannell. 2019. Adoption of agricultural management for Great Barrier Reef water quality improvement in heterogeneous farming communities. Agricultural Systems 79: 1-8.

Van Meter, K.J., P. Van Cappellen, and N.B. Basu. 2018. Legacy nitrogen may prevent achievement of water quality goals in the Gulf of Mexico. Science 360 (6387): 427-430.

Walve, J., M. Sandberg, U. Larsson, and C. Lännergren. 2018. A Baltic Sea estuary as a phosphorus source and sink after drastic load reduction: Seasonal and long-term mass balances for the Stockholm inner archipelago for 1968-2015. Biogeosciences 15 (9): 3003 3025.

Winsten, J.R. 2009. Improving the cost-effectiveness of agricultural pollution control: The use of performance-based incentives. Journal of Soil and Water Conservation 64 (3): 88A-93A.

Winsten, J.R., and M. Hunter. 2011. Using pay-for-performance conservation to address the challenges of the next farm bill. Journal of Soil and Water Conservation 66 (4): 111A-117A.

Zeldis, J.R., C. Depree, C. Gongol, P.M. South, A. Marriner, and D.R. Schiel. 2020. Trophic indicators of ecological resilience in a tidal lagoon estuary following wastewater diversion and earthquake disturbance. Estuaries and Coasts 43 (2): 223-239. 